
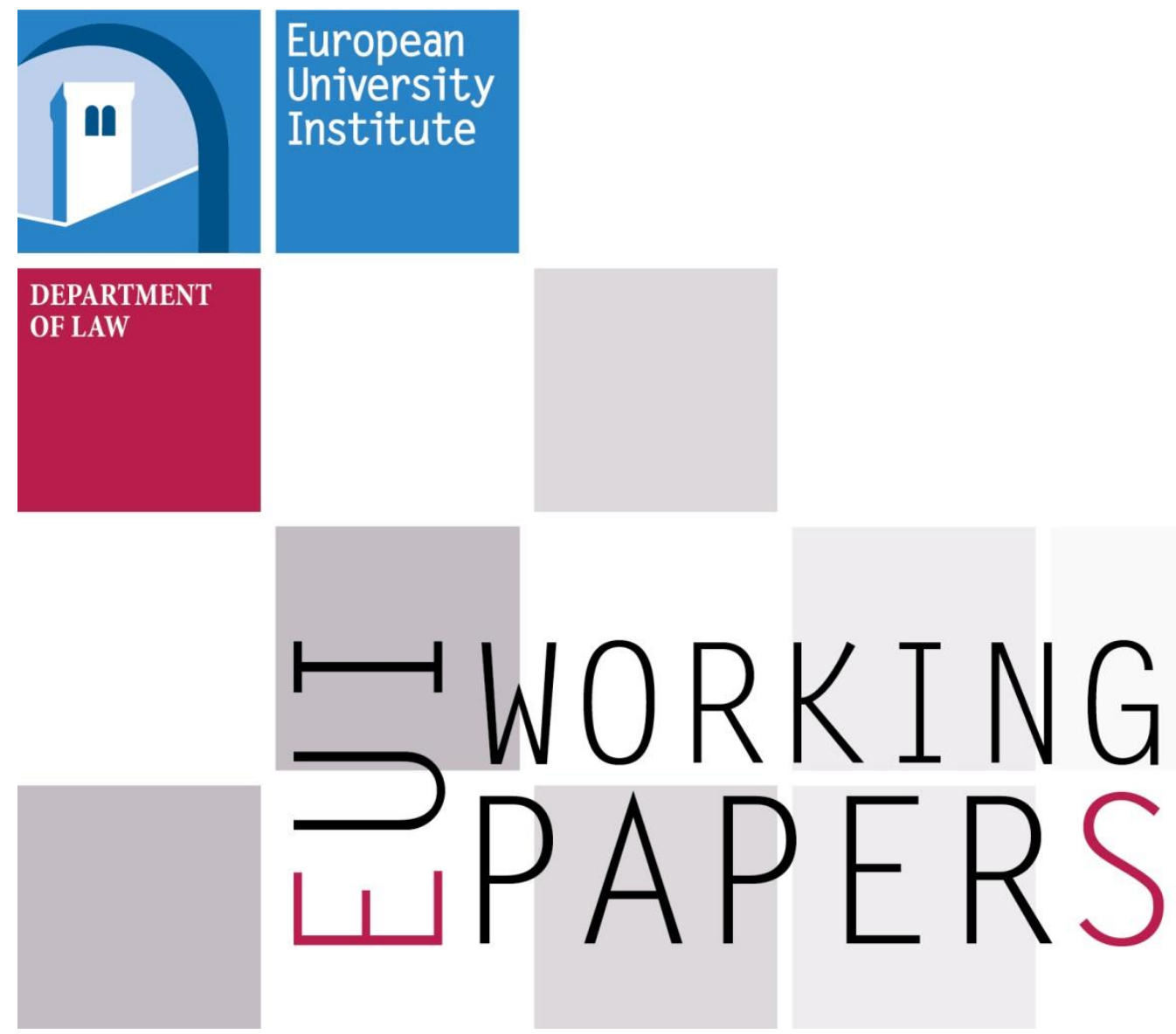

LAW 2017/04

Department of Law

European Regulatory Private Law Project (ERC-ERPL)

European Research Council (ERC) Grant

Shaking the normative foundations of EU equality law: Evolution and hierarchy between market integration and human rights rationales

Raphaële Xenidis

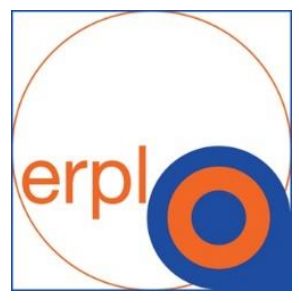



European University Institute

Department of Law

SHAKING THE NORMATIVE FOUNDATIONS OF EU EQUALITY LAW: EVOLUTION AND HIERARCHY BETWEEN MARKET INTEGRATION AND HUMAN RIGHTS RATIONALES

Raphaële Xenidis

EUI Working Paper LAW 2017/04

ERC ERPL Project

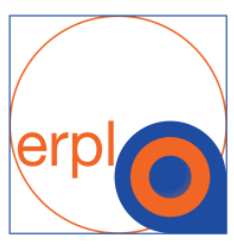


This text may be downloaded for personal research purposes only. Any additional reproduction for other purposes, whether in hard copy or electronically, requires the consent of the author. If cited or quoted, reference should be made to the full name of the author, the title, the working paper or other series, the year, and the publisher.

ISSN 1725-6739

(C) Raphaële Xenidis, 2017

Printed in Italy

European University Institute

Badia Fiesolana

I-50014 San Domenico di Fiesole (FI)

Italy

www.eui.eu 


\section{European Regulatory Private Law: The Transformation of European Private Law from Autonomy to Functionalism in Competition and Regulation (ERPL)}

A 60-month European Research Council grant has been awarded to Prof. Hans-Wolfgang Micklitz for the project "European Regulatory Private Law: the Transformation of European Private Law from Autonomy to Functionalism in Competition and Regulation" (ERPL).

The focus of the socio-legal project lies in the search for a normative model which could shape a self-sufficient European private legal order in its interaction with national private law systems. The project aims at a new-orientation of the structures and methods of European private law based on its transformation from autonomy to functionalism in competition and regulation. It suggests the emergence of a self-sufficient European private law, composed of three different layers (1) the sectorial substance of ERPL, (2) the general principles - provisionally termed competitive contract law - and (3) common principles of civil law. It elaborates on the interaction between ERPL and national private law systems around four normative models: (1) intrusion and substitution, (2) conflict and resistance, (3) hybridisation and (4) convergence. It analyses the new order of values, enshrined in the concept of access justice (Zugangsgerechtigkeit).

The research leading to these results has received funding from the European Research Council under the European Union's Seventh Framework Programme (FP/2007-2013) / ERC Grant Agreement n. [269722].
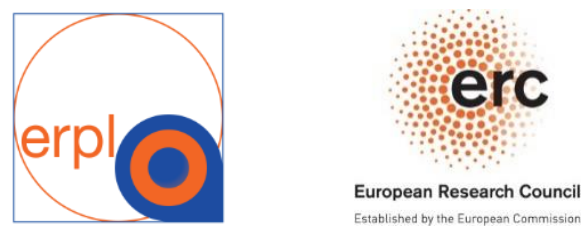
Author contact details:

Raphaële Xenidis

Ph.D. Researcher

Law Department

European University Institute

Villa Salviati

Via Bolognese 126

50139 Florence - Italy

Raphaele.Xenidis@eui.eu 


\begin{abstract}
With the adoption of the Race Equality Directive (2000/43/EC), the Framework Directive (2000/78/EC) and the Gender Directive on goods and services (2004/113/EC), the landscape of EU non-discrimination law has changed dramatically. From a medium to advance market integration, non-discrimination has evolved towards a genuine fundamental right of equality. However, the Court of Justice's efforts to give substance to this general principle of equal treatment have met political backlash. At the same time, while advancing the principle of equal treatment, the reforms have also instilled hierarchy within equality. More than sixteen years after the first comprehensive reforms, in a climate of political mistrust towards the EU, it is unlikely that new legislation will level off the ground. Today, how has the interplay of market-based and fundamental-rights-based rationales transformed the advancement of the principle of non-discrimination in Europe? This paper first examines the shift operated in the EU transformative equality enterprise, from a legislative and adjudicative focus towards a focus on enforcement, as a response to pushback. Second, the paper argues that the interplay between an instrumental market-based and an imperative rights-based understanding of equality, underlying this pushback, has transformed non-discrimination into a hybrid but effective principle. The third section, however, puts forward that the existence and effectiveness of this principle of non-discrimination is threatened by several lines of hierarchy within the European equality monument.
\end{abstract}

\title{
Keywords
}

Non-discrimination; transformative equality; general principle of equal treatment; market vs. fundamental rights; hierarchies 



\section{Table of contents}

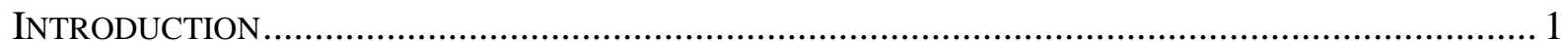

THE EVOLUTION OF EU NON-DISCRIMINATION LAW: THE INCOMPLETE ESTABLISHMENT OF NONDISCRIMINATION AS A TRANSFORMATIVE GENERAL PRINCIPLE............................................ 2

The cooperation between civil society and the European legislator: from comprehensive reforms to backlash

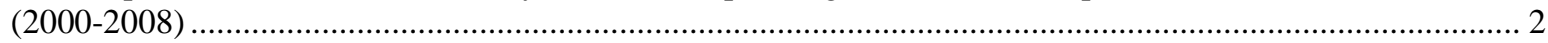

The reforms of the 2000s: completing the non-discrimination landscape .............................................. 3

Privatisation and transformation of the non-discrimination principle .................................................... 4

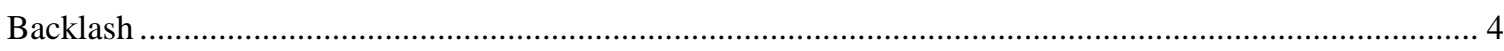

The CJUE's promotion of a general principle of non-discrimination amidst critiques ................................. 6

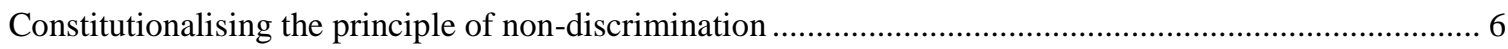

Guaranteeing the principle of effectiveness in non-discrimination jurisprudence ................................... 7

Criticisms and hesitations: concerns over private autonomy and supranational competences ..................... 8

The administrative turn of the EU's fight against discrimination: responding to the blockage through a focus shifting to enforcement.....

Solving the hiatus between a proclaimed general principle of non-discrimination and an incoherent EU equality monument: the policy-based alternative ..................................................................... 11

The combination of administrative and judicial remedies through the equality bodies ............................ 11

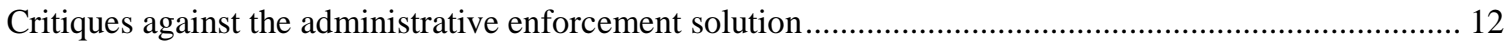

\section{NON-DISCRIMINATION LAW: A RECONCILIATION POINT BETWEEN MARKET-ORIENTED AND}

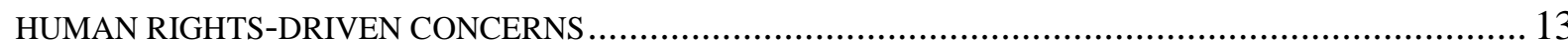

A hybrid model: between market-oriented and human-rights-driven understandings of equality ................. 14

The tension between an imperative and an instrumental vision of equality ......................................... 14

From market integration to equality as a fundamental right: a shifting legitimising narrative................... 15

The hybrid EU non-discrimination model: a difficult balancing of clashing social interests ................... 17

Non-discrimination as a site of reconciliation: equal citizenship through market participation .................... 19

Equality through the market: granting participation of socially marginalised groups through distribution . 19

Equality before the market: recognising identity, accommodating diversity ...................................... 21

Equality beyond the market: non-discrimination through citizenship ................................................... 22

HIERARCHIES IN EU NON-DISCRIMINATION LAW: A DIFFERENTIATED EQUALITY PROTECTION .. 23

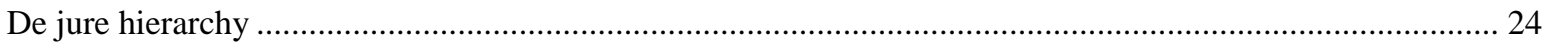

Scope of protection

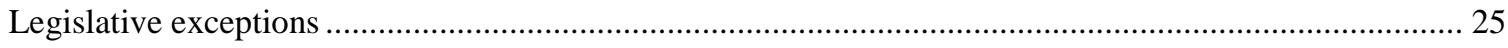

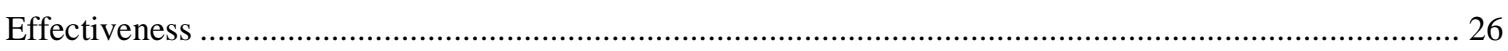

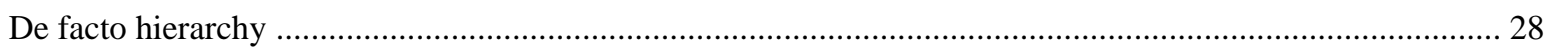

Implementation of exceptions, justifications, remedies and levels of scrutiny by the CJEU ................... 28

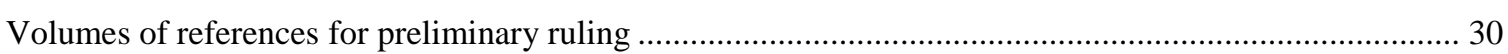


CONCLUSION: A TALE OF TWO DIVERGING RATIONALES, RECONCILED IN A HYBRID BUT

ANNEX

REFERENCES

Case law. 39

Legislation ..... 40

Policy, advocacy and institutional research documents. 41

Secondary sources 41 


\section{Introduction*}

More than one decade ago, pivotal reforms have attracted much attention and brought about important changes to the field of non-discrimination in the European Union (EU). ${ }^{1}$ At the time, the advancement of EU equality law corresponded to an endeavour to ensure equality as a fundamental human right. Both at the legislative and at the normative level, the foundations of EU non-discrimination law have been shaken. The consequences for today's non-discrimination law landscape and in terms of equality advancement deserve attention. On the one hand, the comprehensive reforms expected to level the terrain of EU equality law have failed, ${ }^{2}$ leaving the ground of non-discrimination law uneven. On the other hand, after several decisive breakthroughs, the jurisprudence of the Court of Justice of the European Union (hereinafter 'CJEU' or 'the Court') has amplified the dents in the landscape, sparkling much criticism and resistance. Hence, the transformative effort of the EU to advance equality as a structuring principle of society has remained incomplete. To examine the reasons of this failure, it is necessary to dig deeper to consider how the normative foundations of EU equality law have evolved to sustain this transformation. At the discursive level, it has translated into the blossoming of a new rationale for the principle of non-discrimination. The human-rights-based justification of equality has gained terrain over the historical market-orientated motivation, manifesting itself through the accession to several conventions of fundamental and human rights, and supporting the efforts of the EU to advance, broaden and deepen equality. By a merging of the rights-based approach and the economic discourse within the greater participation-of-all-citizens leitmotiv, the principle of equality has reached a new status, both of instrumental and imperative nature. However, the same political fears and criticisms have encroached on the fusion of 'equality as a means of economic inclusion' and 'equality as a fundamental right', leaving equality fragmented and torn between two opposed, albeit not contradictory, rationales. The resulting tension reflects the incomplete transformation of the equality monument in the EU, leading to the formation of hierarchies that are at odds with the proclaimed uniform principle of equality, not to mention a fundamental right to equality. These hierarchies pose problems by creating a scaled protection that varies for each of the legislated grounds.

This paper aims to give an account of the evolution of EU non-discrimination law (economic discrimination left aside) from the most recent comprehensive reforms until its current seeming stagnation, to identify the actors and policy moves behind this evolution, and to understand the corresponding normative shift that has taken place. More precisely, this paper answers the question of how and why EU non-discrimination law has evolved towards fragmentation, both in its implementation and normative foundations, while the transformative efforts of the EU targeted the advancement of the principle of equality as a whole. The hypothesis underlying this paper is that the transformative efforts

\footnotetext{
* The research leading to these results has received funding from the European Research Council under the European Union's Seventh Framework Programme (FP/2007-2013) / ERC Grant Agreement n. [269722]

${ }^{1}$ Council Directive 2000/43/EC of 29 June 2000 implementing the principle of equal treatment between persons irrespective of racial or ethnic origin [2000] OJ L180/22; Council Directive 2000/78/EC of 27 November 2000 establishing a general framework for equal treatment in employment and occupation [2000] OJ L303/16; Council Directive 2004/113/EC of 13 December 2004 implementing the principle of equal treatment between men and women in the access to and supply of goods and services [2004] OJ L373/37.

See also Directive 2006/54/EC of the European Parliament and of the Council of 5 July 2006 on the implementation of the principle of equal opportunities and equal treatment of men and women in matters of employment and occupation (recast) [2006] OJ L204/23 and Directive 2010/41/EU of the European Parliament and of the Council of 7 July 2010 on the application of the principle of equal treatment between men and women engaged in an activity in a self-employed capacity and repealing Council Directive 86/613/EEC [2010] OJ L180/1.

${ }^{2}$ Communication from the Commission to the European Parliament, the Council, the European Economic and Social Committee and the Committee of the Regions COM/2008/0426 final on a Proposal for a Council Directive on implementing the principle of equal treatment between persons irrespective of religion or belief, disability, age or sexual orientation SEC(2008) 2172 [2008] OJ C303/21 (hereinafter the 'Horizontal Proposal' or the 'Proposal').
} 
of the EU to advance equality have translated into new legitimising discourses and legal reforms, that have however been curbed by critiques and resistance at the political level, leading to fragmentation. As a consequence, the presence of hierarchies create inequality within equality protection, and make it difficult to pursue the advancement of a uniform and consistent principle of non-discrimination. ${ }^{3}$

The argument unfolds along three main ideas. First, this paper argues that the transformative efforts of the European legislator and the CJEU to advance equality as a socially structuring principle have faced resistance at various levels. Opposition coming from member States, social backlash, important scholarly critique and a lack of coordinated mobilisation on the side of civil society groups have contributed to jam the European legislative and judicial efforts towards non-discrimination. This has resulted in a displacement of focus from broadening and deepening to enforcing equality, leaving the non-discrimination landscape uneven. Second, this paper aims to grasp and explain some of the internal tensions and contradictions of today's EU non-discrimination law. The transformative efforts undertaken in the 2000s have been sustained by a change at the discursive level, with the emergence of a rights-based approach to equality as a leitmotiv for reform. The fundamental rights discourse has presented itself as a normative remedy to the instrumental economic rationale that had historically permitted protection against gender and nationality-based discrimination. This patchwork of normative foundations underlying the principle of non-discrimination has contributed to the fragmentation of the EU equality corpus. Finally, the third section of this paper proposes to examine the consequences of this fragmentation by describing the hierarchies that have formed within non-discrimination law in the EU, and the problems they pose in terms of status, transformative reach, effectiveness and applicability of the general equality principle.

\section{The evolution of EU non-discrimination law: the incomplete establishment of non- discrimination as a transformative general principle}

Since the comprehensive reforms of the 2000s, the landscape of EU non-discrimination law has changed completely. In an effort to establish non-discrimination as a core principle within the community, the EU has broadened and deepened its equality protection. Today, however, the transformative reach of the general principle of non-discrimination promoted by the EU faces numerous barriers. This section scrutinises the role of the diverse actors in the reform process, and aims at understanding its evolution and the reasons for its incompleteness, more than a decade after the last legislative reforms in the field.

\section{The cooperation between civil society and the European legislator: from comprehensive reforms to backlash (2000-2008)}

The efforts to increase the hold of the non-discrimination principle over interpersonal relationships in domains of social life beyond employment can be described as the "transformative" nature of equality, in the words of Muir. ${ }^{4}$ The history of the transformative function of the principle of non-discrimination in the EU starts with the battle for equal pay in the middle of the 1970s. ${ }^{5}$ At the time of Defrenne II, the CJEU's activism triggered a long transformation process from a vertical, institutional equality principle mainly regulating the relations between EU member states and their institutions on the one hand, and individuals on the other hand; to a more horizontal principle with regulative power over individual private relationships. ${ }^{6}$ This movement towards the establishment of a transformative EU equality

\footnotetext{
${ }^{3}$ This is not to advocate a one-size-fits-all approach to all grounds. This would not make sense in view of the dramatically different nature of protected grounds such as age and race.

${ }^{4}$ Elise Muir, 'The Transformative Function of EU Equality Law' (2013) 5 European Review of Private Law

${ }^{5}$ The landmark case that has established the horizontal direct effect of the principle of gender equality contained in Article 157 TFEU (ex-Art. 141 TEC) is C-43/75, Gabrielle Defrenne v Société anonyme belge de navigation aérienne Sabena $\left(n^{\circ} 2\right)$ EU:C:1976:56, [1976] ECR 455.

${ }^{6}$ For a complete analysis on this point, see Muir, 'The Transformative Function of EU Equality Law'
} 
principle has been furthered by the important reforms passed in the 2000s (Directives 2000/43/EC, $2000 / 78 / \mathrm{EC}$ and $2004 / 113 / \mathrm{EC}){ }^{7}$ before being stopped in 2008 , with the rejection of the so-called 'Horizontal Proposal', ${ }^{8}$ meant to enhance the uniformity of EU equality protection.

The reforms of the 2000s: completing the non-discrimination landscape

At the turn of the 2000s, EU non-discrimination law was thus subjected to a double motion: one of broadening with the expansion of the equality protection to new grounds, and one of deepening with the expansion of the scope of application of the principle itself. This double move was furthered by the adoption of six new directives which codified the Court of Justice's case law and modernised the field of EU equality law. In 2000, two major pieces of legislation were passed: the Race Equality Directive 2000/43 EC ${ }^{9}$ and the Framework Directive 2000/78. ${ }^{10}$ The main actors behind this change are both EU policy-makers, notably the Commission, pushing for a strengthening of the equality principle, and strongly mobilised civil society actors and transnational advocacy groups working in sync with the European Parliament. ${ }^{11}$ The Race Equality Directive extended the principle of equal treatment to race and ethnicity in the fields of employment and vocational training, social protection, including social security and healthcare, social advantages, education, the media, advertising and the access to and supply of goods and services including housing. It is noticeable that the scope of the directive is very wide, affording the broadest protection against discrimination in the EU so far, in many essential fields of everyday life both in the private and the public sectors. The Framework Equality Directive extended the principle of equal treatment to the grounds of religion or belief, disability, age and sexual orientation, in the field of employment and vocational training only.

In addition to this, the scope of protection from sex discrimination was extended. In the aftermath of the two 2000 directives, the debate on gender equality was revived and legislative amendments were subsequently made to codify and reflect the case law of the CJEU. Directive 2002/73 EC amended the previous Directive 76/207/EEC promoting equal treatment for men and women in the field of employment, notably by including definitions of direct and indirect discrimination and thus enhancing the protection. ${ }^{12}$ Most importantly, Directive 2004/113 EC deepened the scope of the principle of gender equality by extending the protection to the access to, and supply of, goods and services. ${ }^{13}$ In 2006 , Directive 2006/54/EC ${ }^{14}$ modernised and simplified the application of the principle equal treatment on the basis of sex, followed by Directive 2010/41EC ${ }^{15}$ with the same goal in the field of self-employment. Finally, in 2009 the strengthening of non-discrimination law was confirmed by the Lisbon Treaty, which gave constitutional status to the Charter of Fundamental Rights (subsequently 'the Charter'), and hence to its prohibition of discrimination contained in Article 21 and $23,{ }^{16}$ applicable within the scope of EU

\footnotetext{
${ }^{7}$ See (nr. 1)

${ }^{8}$ See (nr. 2)

${ }^{9}$ See (nr. 1)

${ }^{10}$ See (nr. 1)

${ }^{11}$ Crucial transnational stakeholders were for instance the Starting Line Group for the Race Equality Directive, and European Women's Lobby for the directives on gender equality. See for instance the important work done ex ante by the Starting Line Group to prepare the Race Equality directive: Chopin I and Niessen J, Proposals for Legislative Measures to Combat Racism and Promote Equal Rights in the European Union (1998)

${ }^{12}$ Directive 2002/73/EC of the European Parliament and of the Council of 23 September 2002 amending Council Directive $76 / 207 / \mathrm{EEC}$ on the implementation of the principle of equal treatment for men and women as regards access to employment, vocational training and promotion, and working conditions [2002] OJ L269/15

${ }^{13}$ Directive 2004/113/EC see (nr. 1)

${ }^{14}$ Directive 2006/54/EC see (nr. 1)

${ }^{15}$ Directive 2010/41/EU see (nr 1)

${ }^{16}$ European Charter of Fundamental Rights of the European Union [2000] OJ C364/3 Article 21 on non-discrimination states: "1. Any discrimination based on any ground such as sex, race, colour, ethnic or social origin, genetic features, language,
} 
law. In addition, the EU's enterprise to promote equality as a human right manifested itself through the accession to the UN Convention on the Rights of Persons with Disabilities in 2009 and the discussions to access the European Convention on Human Rights, which finally failed in 2014. ${ }^{17}$

\section{Privatisation and transformation of the non-discrimination principle}

The review of the most recent directives confirms the double movement of broadening and deepening of the protection against discrimination. In sum, more grounds are protected, in more areas. This translates into the reinforcement of the so-called privatisation of the principle of equal treatment, which has started to spread horizontally into EU society, and in some cases ruling over private relationships. ${ }^{18}$ This motion is characterised by the fact that more private interactions, beyond the field of employment, are regulated by EU equality law. It reflects a transformative function, through which European societies are reshaped by the direct injection of the equality norm into interpersonal relationships. ${ }^{19}$ Not only does EU equality law regulate the interactions between states and individuals in the public area as it was the case at the beginning of the EU integration process, but it also "modif[ies] interpersonal relationships" 20 between EU citizens in the private sector. Through horizontal direct effects, the principle of equal treatment boosts a form of "inter-personal equality" 21 within the EU, imposing the equality principle at the micro-level of social interactions. ${ }^{22}$ This is most visible when the principle of equal treatment encroaches on private autonomy, notably the freedom of contracts, as can be the case in consumption transactions for race and gender equality protection at the EU level. ${ }^{23}$ However, the transformative reach of the EU equality principle remains limited for several reasons. It is first limited to the protection against discrimination based on some ascriptive identity dimensions and does not touch upon socio-economic status, family status, etc., as national law does. ${ }^{24}$ Second, a balancing between private autonomy and non-discrimination is operated for each ground, and the protection level differs across areas of law and grounds. ${ }^{25}$ Hence, the transformation of EU society through the broadening, deepening and privatisation of the principle of equality is differentiated according to contexts and grounds.

\section{Backlash}

In 2008 , however, a proposal for a new legislation attempted to put an end to this uneven situation by enhancing the transformative bite of EU equality legislation through further regulation of the private

religion or belief, political or any other opinion, membership of a national minority, property, birth, disability, age or sexual orientation shall be prohibited. 2. Within the scope of application of the Treaty establishing the European Community and of the Treaty on European Union, and without prejudice to the special provisions of those Treaties, any discrimination on grounds of nationality shall be prohibited." and Article 23 on equality between men and women states: "Equality between men and women must be ensured in all areas, including employment, work and pay. The principle of equality shall not prevent the maintenance or adoption of measures providing for specific advantages in favour of the under-represented sex."

${ }^{17}$ See Opinion 2/13 pursuant to Article 218(11) TFEU [2014] EU:C:2014:2454

${ }^{18}$ See Nobert Reich, 'The Impact of the Non-Discrimination Principle on Private Autonomy' in Dorota Leczykiewicz and Stephen Weatherhill (eds), The Involvement of EU Law in Private Law Relationships (Hart Publishing 2013)

${ }^{19}$ See Muir, 'The Transformative Function of EU Equality Law'

${ }^{20}$ Ibid, 1241

${ }^{21}$ Ibid, 1253

${ }^{22}$ A good example of this is the recent national judgement Gareth Lee v Colin McArthur, Karen McArthur and Ashers Baking Company Limited [2016] NICA 39. The Ashers Bakery decision finds discrimination on the basis of sexual orientation in a private business transaction between customers and business owners, in application of the Northern Ireland Equality Act (Sexual Orientation) Regulations (NI) 2006 which are broader than Directive 2000/78/EC that only covers employment, and which are intended in the Horizontal Proposal that is still under discussion at the Council.

${ }^{23}$ Reich, 'The Impact of the Non-Discrimination Principle on Private Autonomy', 256

${ }^{24}$ Ibid

${ }^{25}$ Ibid 
relationships of EU citizens. The Commission proposed a directive implementing the principle of equal treatment between persons irrespective of religion or belief, disability, age or sexual orientation in order to extend non-discrimination to all areas of life. ${ }^{26}$ It was meant to remedy the existing gaps in the protection against discrimination in the everyday access of goods and services - domain in which an important proportion of discriminatory behaviours occur - in order to align the protection of sexual orientation, religion, disability and age with the protection of race and gender. ${ }^{27}$ This ambitious reform was meant to extend the horizontal reach to non-discrimination rights outside the fields of employment and vocational training, where these grounds are already protected, in the areas of social protection, including social security and health care; social advantages; education; access to and supply of goods and services available to the public, including housing, both in the public and in the private sector.

The above-mentioned Proposal had the support of the European Parliament and many transnational NGOs. ${ }^{28}$ Nevertheless, this proposal faced strong opposition on the side of certain EU member States in the Council of Ministers, notably Germany, followed by a majority, and was subsequently rejected. ${ }^{29}$ Although they were initially in favour of the idea, EU member states were worried that giving such large competences to the EU would contravene the principle of subsidiarity. EU member states also questioned the need for such a directive, despite it following the logic of equality as a fundamental right promoted by the Treaties and the Charter. ${ }^{30}$ Other opposed governments rejected the inclusion of an access to social protection within the scope of the Proposal. ${ }^{31}$ In addition, market actors insisted on costs to business to oppose the Proposal. Another factor of failure is, to some extent, the latent competition for recognition, resources and agenda-framing among identity-based activist groups. For instance, at the margin some gender activists had expressed concerns that the multiplication of grounds would decrease the political importance and the resources devoted until then to gender equality.

This double backlash - both at the EU member States' level and at the civil society level (notably by German private lawyers) - against the efforts to promote and protect equality within the single market has put a first stop to the integration in this domain. This deadlock has still not been overcome today, in a time where opposition and resistance grow along the lines of rising EU scepticism and a conservative right-wing turn in the member states' polites..$^{32}$ The formula of the 2000 s does not seem a successful counter-recipe anymore. There is no agreement about the future and the direction to take in the fight

${ }^{26}$ See (nr. 2) and see also Commission staff working document accompanying the proposal for a Council directive on implementing the principle of equal treatment between persons irrespective of religion or belief, disability, age or sexual orientation [2008] SEC(2008) 2180. Even if the rhetoric is about a general principle of non-discrimination in "all areas of life", the EU has a limited scope of competence (i.e. labour and consumption).

${ }^{27}$ The willingness to extend the protection also translated into the integration of fundamental rights conventions into the EU legal order. For instance, the EU became party to the UN Convention on the Rights of Persons with Disabilities in 2009 and the Charter of Fundamental Rights became binding the same year.

${ }^{28}$ For instance: AGE Platform Europe, Amnesty International European Institutions Office, European Disability Forum, European Network Against Racism, Social Platform, The European Network on Religion and Belief, The European Region of the International Lesbian Gay Bisexual Trans and Intersex Association, The International Lesbian Gay Bisexual Transgender Queer Youth and Student Organisation. See https://euobserver.com/opinion/124834

${ }^{29}$ Gráinne De Búrca, 'The Trajectories of European and American Antidiscrimination Law' (2012) 60 American Journal of Comparative Law, 10

${ }^{30}$ In addition to this, opposition in EU member states against the Commission's activism manifested itself further in the field of EU gender discrimination law with the EU member states' rejection of the (now withdrawn) Proposal for a Directive of the European Parliament and of the Council amending Council Directive 92/85/EEC on the introduction of measures to encourage improvements in the safety and health at work of pregnant workers and workers who have recently given birth or are breastfeeding [2008] COM (2008) 637 proposing a prolongation of maternity leave for pregnant workers.

${ }^{31}$ See Paul Craig and Gráinne De Búrca, 'Equal Treatment and Non-Discrimination' in Paul Craig and Gráinne De Búrca (eds), EU Law Text, Cases and Materials (Oxford University Press 2015)

32 This includes for instance phenomena like Brexit, the rise of nationalistic populism in Hungary, opposition to same-sex marriage and rising extreme-right wing in France and the Netherlands, the succes of the PEGIDA movement and the AFD party in Germany, etc. 
against discrimination at the supranational level. The scope of EU non-discrimination law, according to member states, should not be broadened outside the scope of EU competencies. Contrary to the generality of Treaty provisions, of the Charter and of gender mainstreaming policies, the message seems to be that the EU should constrain non-discrimination law to a role of safeguard within the realm of autonomous national regulatory welfare states.

\section{The CJUE's promotion of a general principle of non-discrimination amidst critiques}

At the judicial level, the CJEU has historically been an active engine for the promotion of gender equality and non-discrimination based on nationality. Following the tradition of a "judicial construction of EU sex equality law" in which "the transformative potential of EU equality law [was] [considerably enhanced] through a heavily court-based process", ${ }^{33}$ the Court pursued the same strategy of increasing supranational governance in the field of equality after the legislative reforms of the 2000s. This transformation of the European society has started with the horizontal direct effects recognised by the CJEU to Article 157 TFEU in the field of sex discrimination. ${ }^{34}$ Today, as the legislative protection against discrimination has been extended, new horizons have opened for the Court's activism in the field of equality.

\section{Constitutionalising the principle of non-discrimination}

The CJEU has gone further than just enforcing the new directives. It has given signals that advancing equality as a transformative principle of the EU was a priority. Over the course of its post-2000 jurisprudence, the CJEU has in fact progressively carved out a principle of equal treatment and nondiscrimination, to which it has granted de facto constitutional status. Considering the entry into force of the EU Charter of Fundamental Rights, non-discrimination transformed into a binding principle through Article 21 and Article 23. This added to the previously existing Treaty provisions (Article 2 and 3 TEU, Article 8 and 19 TFEU) and made equality a fundamental right. The question that ensued was the extent to which, and the way in which the Court was going to bring these provisions to life, and the extent of the principle's validity within the scope of application of EU law. The CJEU has adopted an activist stance on this point. In the much-commented Mangold ${ }^{35}$ in 2005, the Court has recognised a principle of equal treatment based on age, to which it has granted direct effects in horizontal disputes between EU citizens or private entities. This is quite remarkable, as Mangold reversed the Court's reasoning on nondiscrimination. Instead of deducing the prohibition of discrimination from the relevant directive (2000/78/EC in this case), the CJEU considered the constitutional traditions of EU member states and their common "various international instruments" 36 as emphasised in the directive's recital, as the source of a general principle of non-discrimination of constitutional standing. This principle gives expression to the directive but suffices alone to produce effects. This stance was repeated in 2010 in Kücükdeveci, ${ }^{37}$ another case of age discrimination, where the Court confirmed the existence of this general principle and its horizontal direct effects. The interesting point here is the invocation Article 21 of the Charter as a complementary source of law. As an expression of the genera principle of non-discrimination, its Article 21 is binding between private parties on grounds of age. This was later confirmed in 2011 in the widely-discussed Test-Achats ${ }^{38}$ case, where the Court used the general principle of equality contained

\footnotetext{
${ }^{33}$ Muir, 'The Transformative Function of EU Equality Law', 1241

${ }^{34}$ Marshall [1986] and Defrenne II [1976] make clear that Treaty provisions - but not directives - can have direct horizontal effects in the field of sex discrimination. See (nr. 5)

${ }^{35}$ C-144/04 Werner Mangold v Rüdiger Helm EU:C:2005:709, [2005] ECR I-09981

36 Ibid at [74]

${ }^{37}$ C-555/07 Seda Kücükdeveci v Swedex GMBH \& Co. KG EU:C:2010:21, [2010] ECR I-00365

${ }^{38}$ C-236/09 Association Belge des Consommateurs Test-Achats ASBL and Others $v$ Conseil des ministres [2011] ECLI:EU:C:2011:100
} 
in Article 21 of the Charter of Fundamental Rights as the main normative source to strike down EU law (Article 5(2) of Directive 2000/54/EC), and therefore granted horizontal direct effect to this principle of non-discrimination. This was subsequently confirmed in Chatzi $v$ Ypourgos Oikonomikon ${ }^{39}$ where the Court confirmed that Article 20 of the Charter was an expression of the fundamental nature of the principle of equal treatment ${ }^{40}$ and used this principle of equal treatment to override the secondary law at stake. ${ }^{41}$ This approach was repeated in Dansk Industrit ${ }^{42}$ where the Court used the general principle of equal treatment to strike down national law and confirmed its application between private parties. ${ }^{43}$ This signals a change of perspective where equality acquires the status of a fundamental human right and is realised through constitutionalising the general principle of non-discrimination. ${ }^{44}$ Therefore, questions arise regarding the extent and application of the direct effects of this general principle of nondiscrimination and its impact on private relationships in the EU. The Court's affirmative jurisprudence thus was a game-changer insofar as it went beyond the directives to ensure effectiveness, a goal which might not have been enforced in the absence of this bold judicial interpretation. ${ }^{45}$ One hesitation remains as regards the reach and the circumstances of the affirmation of this general principle of nondiscrimination. It has clearly appeared in the framework of gender and age, ${ }^{46}$ pointing towards a more substantive equality jurisprudence. It has been progressively - but more timidly - extended to other grounds, as Römer ${ }^{47}$ indicates in the context of sexual orientation. However, uncertainties remain, notably in light of the inconsistency of the EU equality monument, fractured by differentiated protection levels anchored in the directives, that might affect the very existence and reach of the general nondiscrimination principle.

\section{Guaranteeing the principle of effectiveness in non-discrimination jurisprudence}

The CJEU has made clear that the directives should be interpreted as extensively as possible, in order to provide effective and substantive protection against discrimination. This principle of effectiveness can be observed through several jurisprudential innovations. In Coleman $^{48}$ in 2008, the Court recognised that so-called 'discrimination by association' amounts to discrimination. In Feryn ${ }^{49}$ in 2008, the Court established a presumption of direct racial discrimination and shifted the burden of proof onto the

${ }^{39}$ C-149/10 Zoi Chatzi v Ypourgos Oikonomikon [2016] ECLI:EU:C:2010:534

${ }^{40}$ Ibid at [63]

${ }^{41}$ Ibid at [75]

${ }^{42}$ C-441/14 Dansk Industri (DI) v Succession Karsten Eigil Rasmussen EU:C:2016:278, [2016]

${ }^{43}$ This has been labelled as the "subsidiary direct horizontal effects" of the general principle of non-discrimination by some commentators. See Giovanni Zaccaroni, 'More on the horizontal direct effect of the principle of nondiscrimination on the ground of age: Dansk Industries (DI)' (EU Law Analysis, 14 July 2016)

${ }^{44}$ See Muir, 'The Transformative Function of EU Equality Law', 1244 and Reich, 'The Impact of the Non-Discrimination Principle on Private Autonomy', 256-260

${ }^{45}$ Muir, 'The Transformative Function of EU Equality Law', 1249-1252 and in particular at 1244.

${ }^{46}$ According to Kilpatrick, the Court's "constitutional innovations", observable in the framework of age discrimination case law, in fact serve the goal of developing the "contours of a new and distinctive substantive discrimination architecture". See Claire Kilpatrick, 'The Court of Justice and Labour Law in 2010: A New EU Discrimination Law Architecture' (2011) 40 Industrial Law Journal 280, 283

${ }^{47}$ C-147/08 Jürgen Römer v Freie und Hansestadt Hamburg EU:C:2011:286, [2011] ECR I-03591. In this case the Court affirmed the existence of a general principle of non-discrimination as regards sexual orientation, but still adopted a restrictive approach, stating that neither Directive 2000/78/EC nor Article 19 TFEU (ex-Article 13 EC) could link this principle to the scope of the Union's competences. See Römer [59]-[61].

${ }^{48}$ C-303/06 Coleman v Attridge Law and Steve Law EU:C:2008:415 [2008] ECR I-05603

${ }^{49}$ C-54/07 Centrum voor gelijkheid van kansen en voor racismebestrijding v Firma Feryn NV EU:C:2008:397, [2008] ECR I05187 
defendant. In Meister ${ }^{50}$ in 2012, a case of alleged employment discrimination on the multiple bases of age, gender and ethnic origin, the Court clearly mentioned effectiveness in its concerns. ${ }^{51}$ Finally, in Nikolava ${ }^{52}$ decided in 2015, the Court identified discrimination based on racial stereotyping. A few further examples show how the Court has pushed for effectiveness across a wide range of contexts, but especially in the issues of age, and - to a lesser extent - disability, after historically promoting equality on the basis of gender and nationality. In Danosa ${ }^{53}$ the Court has rendered possible the protection of a member of a board of directors from discrimination on the grounds of pregnancy, considered as direct sex discrimination. In Kücükdeveci ${ }^{54}{ }^{4}$ ennigs ${ }^{55}$ and Prigge,${ }^{56}$ the Court held that the age discrimination at stake lacked an adequate justification. In Rosenbladt ${ }^{57}$ and Georgiev, ${ }^{58}$ the CJEU declared the compatibility with EU law of national rules concerning the automatic termination of contracts on grounds of age. This case law evolution shows how the Court was an active engine for the protection of the new grounds, and in particular for age discrimination, followed by disability. In so doing, the CJEU has not only taken into account the letter of the law, but also its spirit in giving weight to secondary objectives expressed in directives and policy documents as a source of interpretation, thus ensuring their effectiveness. For instance, the directive recitals, the Employment Guidelines for 2000 and the United Nations Convention on the Rights of Persons with Disabilities, to which the EU has become a party, were cited in Odar in $2012^{59}$ and the joined cases Ring and $H K,{ }^{60}$ decided in 2013. The Court has therefore used the principle of effectiveness to advance the implementation of the legislative reforms of the 2000s, while at the same time putting more emphasis on the protection of certain grounds - gender, age, followed by disability - as opposed to others - sexual orientation or religion for instance.

Criticisms and hesitations: concerns over private autonomy and supranational competences

However, harsh criticisms have followed the Court's ventures in its interpretation of the new directives and the Charter, especially after the jurisprudential series from Mangold ${ }^{61}$ to Kücükdeveci ${ }^{62}$ and later Test-Achats. ${ }^{63}$ The backlash was twofold. On the one hand, in view of the proclamation of a general principle of non-discrimination, concerns were raised as regards the autonomy of private parties and their freedom to conduct business. The general principle was perceived as too heavy a regulatory burden for them to accommodate. Critics denounced the Court's efforts to shoehorn the principle of non-

${ }^{50}$ C-415/10 Galina Meister v Speech Design Carrier Systems GmbH EU:C:2012:217 [2012], [39]: "It is not, however, inconceivable that a refusal of disclosure by the defendant, in the context of establishing such facts, is liable to compromise the achievements of the objective pursued by that directive and, in particular to deprive that provision of its effectiveness" (emphasis added). However, the principle of effectiveness is overridden by other concerns.

${ }^{51}$ Ibid at [38] and [39]

${ }^{52}$ C-83/14, CHEZ Razpredelenie Bulgaria AD v Komisa za zashtita ot diskiminatsia EU:C:2015:480, [2015]

${ }^{53}$ C-232/09 Dita Danosa v LKB Lìzings SIA EU:C:2010:674, [2010] ECR I-11405

${ }^{54}$ Kücükdeveci [2010] (nr. 37)

55 Joined cases C-297/10 and C-298/10 Sabine Hennigs $v$ Eisenbahn-Bundesamt and Land Berlin v Alexander Mai EU:C:2011:560, [2011] ECR I-07965

${ }^{56}$ C-447/09 Reinhard Prigge and Others v Deutsche Lufthansa AG. EU:C:2011:573 [2011] ECR I-08003

${ }^{57}$ C-45/09 Gisela Rosenbladt v Oellerking Gebäudereinigungsges. mbH. EU:C:2010:601, [2010] ECR I-09391

${ }^{58}$ C-250/09 Vasil Ivanov Georgiev v Tehnicheski universitet - Sofia, filial Plovdiv. EU:C:2010:699, [2010] ECR I-11869

${ }^{59}$ C-152/11, Johann Odar v Baxter Deutschland GmbH EU:C:2012:772, [2012]

${ }^{60}$ Joined cases C-335/11 and C-337/11 HK Danmark, acting on behalf of Jette Ring $v$ Dansk almennyttigt Boligselskab and HK Danmark, acting on behalf of Lone Skouboe Werge v Dansk Arbejdsgiverforening acting on behalf of Pro Display A/S EU:C:2013:222, [2013]

${ }^{61}$ See (nr. 35)

${ }^{62} \mathrm{See}$ (nr. 37)

${ }^{63}$ See (nr. 38) 
discrimination into a rigid fundamental rights principle with "strong moral status" 64 in order to pursue a form of inter-personal equality. On the other hand, many - and not least the member states - were concerned about the new repartition of competences following from the Court's jurisprudential interpretations after the reforms and the access of the general principle of equal treatment to a constitutional status. Scholars also accused the Court to go beyond its competencies and the controversy led some detractors to call for stopping the activism of the CJEU. For instance, after Mangold, German lawyers publicly appealed to "Stop the ECJ!" claiming that the decision was "only one of many judgments significantly interfering with competences of the member states" ${ }^{65}$ Herzog and Gerken went so far as to call for a judicial watchdog above the CJEU. For instance, in Test-Achats ${ }^{66}$ in 2011, the CJEU was criticised for striking down a legislative provision restricting gender equality in Directive 2004/113/EC for being contrary to Articles 23 and 21, thus confirming the centrality of the Charter, and of equality as a human right, in EU law. More generally, critiques perceived a danger that the Court, through an extensive interpretation of the non-discrimination principle, goes beyond the boundaries of Art. 19 TFEU (ex-article 13 of the EC Treaty). The conflict is linked to the fear that the EU breaches the subsidiary character of non-discrimination clauses and deprives the EU member states from their ability to choose their own measures to achieve the aims set by the EU.

By contrast, the message of the CJEU seems to be that the full range of rights enshrined in the Charter and in the general principle of non-discrimination should be enforced within the strict scope of EU law ${ }^{67}$, and that exceptions must be only strict and narrow. ${ }^{68}$ The Court, albeit ambiguous on the nature of the general principle of non-discrimination, did not shy away from punctually interfering with member states' competences and autonomy to enforce it. Age discrimination cases, notably, were a good opportunity for the Court to ensure the general principle of non-discrimination as a condition for deepening the integration of labour markets. The question is however whether, if market integration per $s e$ is not concerned, the CJEU would be willing to enforce this general principle, especially if controversial cultural issues are at stake. This limits the reach of non-discrimination as a fundamental right. In this perspective, it is astonishing to see that in some cases, like Tyrolean Airways ${ }^{69}$ and Vital Pérez ${ }^{70}$, the CJEU did not consider necessary to examine the questions referred in the light of the Charter, even though the referring courts specifically asked for an interpretation of the non-discrimination provision contained in Article 21 of the Charter. In Römer, the Court found the existence of a general principle of equal treatment, but does not mention the Charter as one of its sources, but instead "various international instruments and from the constitutional traditions common to the [m]ember [s]tates".71 These uncertainties have limited the Court's advancement of a transformative principle of nondiscrimination.

\footnotetext{
${ }^{64}$ Muir, 'The Transformative Function of EU Equality Law', 1253

${ }^{65}$ R. Herzog and L. Gerken, 'Stop the European Court of Justice' Published on 8 September 2008 in the Frankfurter Allgemeine Zeitung (FAZ).

${ }^{66}$ Test-Achats [2011], see (nr. 38)

${ }^{67}$ At the same time, the Court has made clear that the Charter could not generate new protected grounds or extend the meaning of existing grounds. See C-354/13 Fag og Arbejde (FOA) acting on behalf of Karsten Kaltoft v Kommunernes Landsforening (KL) acting on behalf of the Municipality of Billund EU:C:2014:2463, [2014], at [36], [37] and [39] where the Court stated that obesity cannot constitute a form of disability, neither based on Directive 2000/78/EC nor based on the Charter, and C-13/05 Sonia Chacón Navas v Eurest Colectividades SA. EU:C:2006:456, [2006] ECR I-06467 at [56] where the Court explained that the scope of application of Directive 2000/78/EC could not be extended by analogy of the grounds explicitly protected in its Article 1. The same reasoning was applied in Coleman [2008] at [46] see (nr. 48).

${ }^{68}$ See the age discrimination case law series, e.g. C-341/08 Domnica Petersen v Berufungsausschuss für Zahnärzte für den Bezirk Westfalen-Lippe EU:C:2010:4, [2010] ECR I-00047; Prigge [2011] (nr. 56); C-476/11 H.K. Danmark acting on behalf of Glennie Kristensen v Experian A/S EU:C:2013:590, [2013]

${ }^{69}$ C-132/11 Tyrolean Airways Tiroler Luftfahrt Gesellschaft mbH contre Betriebsrat Bord der Tyrolean Airways Tiroler Luftfahrt Gesellschaft mbH. EU:C:2012:329, [2012] at [23]

${ }^{70}$ C-416/13 Mario Vital Pérez v Ayuntamiento de Oviedo EU:C:2014:2371, [2014] at [25]

${ }^{71}$ Römer [2011] at [56] and [60]. See (nr. 47)
} 
The recent CJEU case law therefore reveals a tension. On the one hand, it seems to engage with a humanrights-driven discourse - as promoted by the EU Commission -supported by the existing European and international fundamental rights instruments, where equality is placed as a fundamental right and a constitutional principle. On the other hand, the Court seems careful about the respect of the scope of EU law and about future constitutional innovations, in an effort to avoid further controversy. As a consequence of this conflict, sixteen years after the main reforms of the 2000s and despite important furthering of the protection from discrimination, the situation suffers from the unevenness of the EU equality monument and from social backlash. This ambivalence linked between advancing equality and avoiding controversy has made the Court appear as a less active engine of EU integration in the field of equality. ${ }^{72}$ Since an important and ground-breaking case law on age discrimination already exists, further case law appears more technical and less doctrinal. At the same time, the protection of other grounds is clearer in the sense that it does not pose as many questions in terms of national legislation, which is by contrast rich as regards to age related pensions and regulations. This produces an impression of stagnation whereby non-discrimination case law mainly focuses on age and has been less proactive for other grounds. Notably, the Court's response to AG Kokott's proposition to recognise and condemn intersectional discrimination in Parris has been negative, thus closing the door to advancing nondiscrimination through doctrinal innovations. ${ }^{73}$ In addition, if the reference for preliminary ruling on religion in the Bougnaoui case ${ }^{74}$ still lets a window open to a more protective stand on religious discrimination, the judgement in Achbita leaves no doubt as regards the restraint of the Court amidst the current political climate in Europe. From timidity and hesitations regarding future innovations in nondiscrimination doctrine, the Court's decision in Achibta brings the equality battle to a new level of resignation ${ }^{75}$. National and social backlash has gotten into the judges' and the legislator's way, proposals to enhance current legislation face a deadlock, and social mobilisation seems to not be enough to drive the integration process further in this field. Hence, many shades remain about where the interpretation of the new directives will take us, and about the future orientation of the general principle of nondiscrimination in the EU. Therefore, substantive equality, despite efforts to transform nondiscrimination into an effective and constitutional general principle, remains an area under construction. ${ }^{76}$

${ }^{72}$ The Court's decision in Achbita confirms this hypothesis. See C-157/15 Samira Achbita and Centrum voor gelijkheid van kansen en voor racismebestrijding v G4S Secure Solutions NV EU:C:2017:203, [2017]

${ }^{73}$ C-443/15 David L. Parris v Trinity College Dublin and Others EU:C:2016:897, [2016]

${ }^{74}$ C-188/15 Asma Bougnaoui and Association de défense des droits de l'homme (ADDH) v Micropole SA EU:C:2017:204, [2017]

${ }^{75}$ In Achbita the Court finds the rule at stake neutral because equally prohibiting religious garments and political and philosophical signs, hence completely misconstruing the imperative nature of religious dress requirements, of which no comparison can be found for political or philosophical beliefs. The Court therefore promotes a biased concept of neutrality which in fact only permits cultural identification with well-assimilated Western codes. It is especially clear from the facts in Achbita that the written rule prohibiting the Islamic headscarf was adopted ad hoc to prevent the applicant from expressing her religious and cultural identity at work. In this perspective, not recognising direct discrimination (disguised as a neutral general rule) is equivalent to accepting covert discrimination based both on religion and ascriptive racialisation (protected under race discrimination in EU law), coupled to discrimination based on cultural membership (which not covered by EU law, but could be understood as a form of racialisation). The only window left open by the Court is the indirect discrimination way (which the French referring court did not even mention in its questions to the CJEU), which the EU judges however considered justifiable, even though it remains for the national court to decide on this last point.

${ }^{76}$ Kochenov argues that the EU needs a substantive equality principle, which is still missing today although the European Commission promotes a concept of substantive equality in policy debates. See Dimitry Kochenov, 'Citizenship without Respect: The EU's Troubled Equality Ideal' (2010) Jean Monnet Working Paper 08/10, 10 


\section{The administrative turn of the EU's fight against discrimination: responding to the blockage through a focus shifting to enforcement}

Solving the hiatus between a proclaimed general principle of non-discrimination and an incoherent EU equality monument: the policy-based alternative

The impossibility to overcome the blockage stemming from the combined backlash from EU member states and observers has led to the search for a different path. In fact, while no further legislative reform is conceivable and the CJEU's own advancement of a general principle of non-discrimination has faced resistance, the European Commission continues to promote substantive equality through different means. In fact, the funding and production of numerous research and policy documents as well as enforcement reports during the past years bear witness to the institutional attempts to consolidate equality in a time of deadlock and interrogations regarding the coherence of EU law. ${ }^{77}$ These new efforts by the European Commission displace the focus from law-making and adjudication onto enforcement and policy-based solutions. They reflect a "shift away from traditional judicial remedies and towards renewed administrative as well as other more innovative approaches" ${ }^{78}$ The enforcement issue thus has been occupying the space through several channels: policy reports and expertise about the implementation of non-discrimination measures in EU member states (for instance in the field of Roma rights, multiple discrimination, substantive equality, etc.), recommendations made to national policy-making authorities, research, surveys and advocacy enterprises, communication through awareness-rising and education campaigns, training of special instances and employers in member states, etc. These missions are notably the mandate of EU equality bodies and the European Equality Law Network, the latter being specialised in producing research and policy recommendations.

The combination of administrative and judicial remedies through the equality bodies

Today, we therefore face a transition from exclusively judicial to a combination of both judicial and policy-based as well as administrative enforcement mechanisms. ${ }^{79}$ This is part of the transformative efforts to place equality at the centre of the social life of EU citizens. This noticeable phenomenon emerged after the enactment of Directives 2000/43 and 2004/113/EC, 2006/54/EC and 2010/41/EC ${ }^{80}$ which imposed to the EU member states the creation of specialised equality bodies in the fields of race and gender equality, whose role it is to assist victims seeking remedies, and to inform policy-makers and private and public economic actors about non-discrimination law, its requirements and good practices. While UK, Sweden and the Netherlands already had equality bodies before, the rest of the EU had to implement this new measure. This "new wave of antidiscrimination law" $" 81$ however reinforces the issue of unbalance in EU equality law. It poses the question of why create equality bodies were made compulsory by the Race Equality Directive and further gender equality directives but not by the almost contemporary Framework Employment Equality Directive. ${ }^{82}$ This administrative development was inspired by the US model and pushed through by the EU Commission as a way to secure better application of EU law in an era of backlash and blockage. It obtained the support of an "international movement for the creation of human rights institutions" ${ }^{83}$ seen as an alternative way for poor and

\footnotetext{
${ }^{77}$ See Dimitry Kochenov, 'Citizenship without Respect: The EU's Troubled Equality Ideal' (2010) Jean Monnet Working Paper $08 / 10$

${ }^{78}$ De Búrca, 'The Trajectories of European and American Antidiscrimination Law', 1

${ }^{79}$ See Bruno De Witte, 'New Institutions for Promoting Equality in Europe: Legal Transfers, National Bricolage and European Governance' (2012) 60 American Journal of Comparative Law

${ }^{80}$ See (nr. 1)

${ }^{81}$ De Witte, 'New Institutions for Promoting Equality in Europe: Legal Transfers, National Bricolage and European Governance', 50

${ }^{82}$ Ibid 52

${ }^{83}$ Ibid, 54
} 
marginalised people to secure enforcement while they cannot always access the judiciary and the political debate. On her side, De Búrca explains this phenomenon by analogy with the US example, where political backlash has curbed and shrank progressive interpretations of non-discrimination law by the judiciary, so that a novel, often non-court-centred, series of means to promote social justice has emerged. ${ }^{84}$ The creation of administrative organs such as the equality bodies nevertheless does not leave the judiciary out of the picture. On the contrary, it also sponsors judicial implementation of equality. In fact, equality bodies have played an important role in mobilizing national courts in order to promote the enforcement of EU non-discrimination rights, notably by pushing for referrals to the CJEU. Historically, the Equal Opportunities Commission in the UK, has served as a model for this role, instigating progressive judicial interpretation and enforcement of EU gender equality law in the 1960s and 1970s. ${ }^{85}$ This role has recently been taken on by the Belgian Centre for Equal Opportunities and Opposition to Racism, linked to the Interfederal Center for Equal Opportunities, in Feryn ${ }^{86}$ and in the Achbita ${ }^{87}$ case, thus bringing newly legislated grounds of discrimination to judicial scrutiny and pushing for enforcement.

Subsequently the equality bodies became a fix ingredient in the efforts to promote the transformative role of EU non-discrimination law. The Proposal to extend the protection of the other grounds also foresaw the establishment of multi-ground equality bodies before its failure. However, many national equality bodies in reality cover more grounds than just gender and race. ${ }^{88}$ The current trend is to amalgamate the protection of human rights and from discrimination within unique bodies, ${ }^{89}$ confirming the shift towards a human-rights based understanding of equality. France provides a good example, with the previous Haute Autorité de lutte contre les discriminations et pour l'égalité, specialised in nondiscrimination and equality questions, replaced by the more general Défenseur des droits, which has the broader mission of protecting fundamental rights, among which equality. With this new development, we can observe that the EU Commission still plays an important role - however shifted to a more bottom-up strategy - in the enforcement of equality through a close monitoring work and financial leverage.

\section{Critiques against the administrative enforcement solution}

The administrative turn towards equality bodies as enforcement and diffusion organs - a manifestation of the evolution EU non-discrimination law towards a more transformative right-based discourse - has not been spared from the criticisms against the EU's incursion in daily private relationships. Notably, a big chunk of these critiques came from German private lawyers, legal scholars and politicians who strongly opposed the post-2000 EU anti-discrimination laws. This slowed down the creation of the equality bodies demanded by EU law in Germany. While the transposition deadline for Directive 2000/43/EC was 2003, many other national equality bodies were set up in 2003 and 2004, the German Federal Anti-Discrimination Agency was only set up in $2006 .{ }^{90}$ The critics denounced the horizontal effects of the non-discrimination rights to be enforced by the equality bodies - gender and race affecting private parties outside the employment field. This was perceived to be encroaching too much

\footnotetext{
${ }^{84}$ De Búrca, 'The Trajectories of European and American Antidiscrimination Law', 19-22

${ }^{85}$ See Hans-W Micklitz, 'The reconstruction of the equal treatment litigation', The Politics of Judicial Co-operation in the EU Sunday Trading, Equal Treatment and Good Faith (Cambridge University Press 2005), 165-291

${ }^{86}$ Feryn [2008] (nr. 49)

${ }^{87}$ Achbita [2017] (nr. 71)

${ }^{88}$ See for instance the French Défenseur des Droits (22 grounds covered including all EU protected grounds), the German Antidiskriminierungsstelle des Bundes (all 6 grounds covered by EU law) and the British Equality and Human Rights Commission (9 grounds covered among which all EU protected grounds).

${ }^{89}$ See Bruno De Witte, 'The crumbling public/private divide: horizontality in European anti-discrimination law' (2009) 13 Citizenship Studies 515

${ }^{90}$ Yet, the German Equality Body, FADA, has a far broader mandate than demanded by EU law.
} 
upon the principles of contractual autonomy and freedom. Another set of critiques concerned the dilution of equality protection, notably because of shrinking resources devoted to the protection of more and more grounds. ${ }^{91}$ Certain gender activists have for instance expressed concerns over the dilution of the gender problematic among other non-discrimination grounds.$^{92}$ In 2015, gender experts denounced the fact that gender equality was in a state of stagnation in the EU. ${ }^{93}$ In parallel, activists against genderbased and disability-based discrimination put forward the need for specific directives, realised in the case of gender (which has a complete separate architecture), but nor in the case of disability. Some commentators deplore the fact that the former coalitions and instruments, the so -called "velvet triangle" (EU institutions, civil society, academia), successful in the past, are no longer effective. ${ }^{94}$

All in all, however, the turn to enforcement and the focus put on administrative and policy-based solutions, with a direct contact to citizens and employers through the equality bodies at the national level, confirms the transformative equality hypothesis. Thereby, the EU has found a less top-down and more bottom-up approach to enforce equality safeguards at the level of member states by bringing together civil society actors, experts, trade unions and NGOs and public administrations. The transition from an exclusively individual and corrective judicial model to a more collective policy- and preventionbased model through a modernisation of national institutions dealing with equality responds to effectiveness and implementation concerns. Interestingly, this shift reveals a crucial tension. By promoting a foundational rhetoric of substantive equality, the limits of which are however flagrant in practice, it seems to be stuck in between two principles. One the one hand, conservative criticisms highlight the need to stick with the EU equality law's historical mandate of market integration, and on the other its transformative ambitions reveal a human-rights driven legitimising discourse. These two rationales seem to be in opposition and hence to create a normative clash shaking the foundations of EU equality law.

\section{Non-discrimination law: a reconciliation point between market-oriented and human rights-driven concerns}

The EU's efforts to protect equality as a fundamental right show a discursive reframing associated with a transition to a more substantive conception of equality through new legislations, court-based and new enforcement modi. The story of the principle of non-discrimination is however clearly rooted in an instrumental conception of equal treatment as means for economic integration. Yet, in recent years, the human rights dimension of equality has gained momentum as a justification and legitimization narrative. ${ }^{95}$ According to Prechal, judge at the CJEU, "[t] $\mathrm{t}$ he process of transformation is firmly coupled to the shift in the rationales underlying equality and non-discrimination: from economic integration motives to more socially oriented concerns to the protection of human dignity, autonomy and

${ }^{91}$ See Sylvia Walby, Jo Armstrong and Sofia Strid, 'Intersectionality and the Quality of the Gender Equality Architecture' (2012) 19 Social Politics: International Studies in Gender, State \& Society 446

${ }^{92}$ See Eva Maria Hinterhuber and Veronica Vasterling, 'Gender and Diversity Studies in European Perspectives: International conference, 8-10 January 2015, Rhine-Waal University of Applied Sciences, Kleve' (2015) 5 Gender : Zeitschrift für Geschlecht, Kultur und Gesellschaft

${ }^{93}$ See the diverse contributions in ibid.

${ }^{94}$ See the contribution made by Anne van der Vleuten in ibid.

${ }^{95} \mathrm{~A}$ finer look at the EU's integration history reveals that the human rights rationale has always been a long-term goal of the Union, but was left aside in favour of economic integration for the purpose of finding a compromise on the modes of integration at the beginning of the European construction. See Gráinne De Búrca, 'The Road Not Taken: The EU as a Global Human Rights Actor' (2011) 105 The American Journal of International Law 649.

The human rights rationale has recently re-appeared as a guiding and legitimising principle, first for the Union's external action, and subsequently for its internal action in a time of existential, economic and values crisis. 
personality" ${ }^{96}$ This reflects well the tension between imports from international human rights discourses, emphasising a form of per se validity of equality protection on the one hand; and utilitarian norms of market-based non-discrimination as long found in EU law. The demands of these two rationales seem irreconcilable. In fact, the promotion of a general principle of non-discrimination seen as a fundamental right corresponds to an imperative understanding of equality. It exists in tension with the historical instrumental mandate of non-discrimination as a facilitator for economic integration. This tension is observable in the jurisprudence of the CJEU. The Court has at times identified a general principle of non-discrimination as a fundamental right, emanating from inter alia the Charter, which imposes itself on market relationships, while on the contrary sticking to the text of the directives at other times, with no direct horizontal effect. ${ }^{97}$ This mixture of legal norms, origins and rationales puts the CJEU in a difficult position, thus opening the door for criticisms regarding the Court trespassing its domain of competence. This section investigates how the evolution of the normative and moral foundations of EU equality law underlies the transformative turn described in the first section. A reflection about the foundational narratives of recent EU non-discrimination law also sheds light on the apparent contradictions of its evolution.

\section{A hybrid model: between market-oriented and human-rights-driven understandings of equality}

The tension between an imperative and an instrumental vision of equality

The EU non-discrimination law and jurisprudence is not born as a genuine effort to protect a fundamental right of equality. The roots of EU non-discrimination law are to be found in the efforts to realise a single market without competition distortions, that is to integrate national markets and to ensure the freedom of circulation of workers. For this reason, at its origins the prohibition to discriminate logically concerned two core characteristics which were held responsible for causing distortions of competition among EU workers, namely nationality and sex. ${ }^{98}$ Hence, non-discrimination rights primarily served the purpose of boosting economic participation, and thus growth. France is responsible for pushing for equal pay between men and women, seen as conditio sine qua non to avoid unfair competition, thus instilling gender equality in the European integration process. ${ }^{99}$ With the reforms of the 2000s, however, an alternative rationale has emerged, related to a vision of equality as a human right and to the search for a fundamental set of values for the Union. This competition between a market- and a rights-based narrative of non-discrimination plays out at two levels. First, a difference between 'market' and 'beyond market' rationales can be drawn in terms of origins and justification of equality protection. While the "old" grounds - gender and nationality - arose from market-related concerns, the new grounds have mainly been supported by human-rights driven justifications, except for age which is the product of hybrid concerns. Second, the opposition plays out in the differences between material scope of the various directives. the directives protecting certain grounds from discrimination are associated to different material scopes. Some are protected only within the realm of the market (employment, consumption, etc.), and some are more largely protected (i.e. race and gender, for instance in the media, education, etc.). However, some fundamental criticisms pertain to the market emphasis to the disadvantage of a fundamental right to equality. A pessimistic way to frame the mandate of EU equality

\footnotetext{
${ }^{96}$ Sacha Prechal, 'Discrimination does not fall down from heaven': the context and evolution of non-discrimination in EU law (Eric Stein Working Paper, 2009), 13

${ }^{97}$ See Craig and De Búrca, 'Equal Treatment and Non-Discrimination'

${ }^{98}$ During the negotiations of the Rome Treaty, France argued that a principle of equal pay for women and men was necessary to avoid market and competition distortions among Member States. It is however only well after the adoption of the relevant Treaty provision in 1957, in fact during the 1970s, that the CJEU has been active in promoting gender equality.

${ }^{99}$ Examples are for instance policy documents regarding the integration of Roma communities, or the 'European Disability Strategy 2010-2020', EU documents on substantive equality such as European Commission, Tackling Multiple Discrimination: Practices, Policies and Laws, 2007) or European Commission, Green paper: Equality and nondiscrimination in an enlarged European Union (28/05/2004)
} 
law is as a protection of an EU "transnational substantive economic due process". ${ }^{100}$ This critique tends to stress the fact that discrimination law in the EU still serves the purpose of facilitating fair competition by avoiding unjustified distortions, barriers to market entry and participation, and this in a system where different national social models are confronted at the transnational level. However, both understandings of equality with their different focal points are needed in a perspective of substantive equality. ${ }^{101}$ Economic as well as recognition-based aspects are complementary. ${ }^{102}$ Hence some confusion arises out of this rhetorical opposition between a 'market' and a 'beyond market' logic of equality. The next sections explain how both narratives of equality played out in the transformation of EU nondiscrimination landscape until today.

From market integration to equality as a fundamental right: a shifting legitimising narrative

While the historic origins of EU non-discrimination law are well-known, its newer underlying rationale has counted a lot towards the recent evolution of EU non-discrimination law, and therefore deserves attention. The latest reforms in non-discrimination law in the EU have been greatly influenced by the discourses and emphasis on the EU as a promoter of rights. After decades of putting aside the human rights project in order to privilege economic integration, the Union's human rights era manifested itself in two ways: externally through international security and peacebuilding missions, and internally by putting forward a new rationale for equality protection. It progressively started after the Maastricht Treaty, with a preliminary liberation from market logics through the creation of a European citizenship, granting rights to European citizens beyond the labour market. ${ }^{103}$ Yet, the year 2000 marks the real beginning of the fundamental rights era for the EU, with the adoption of the Charter. The Lisbon Treaty was a new turn for fundamental rights. In 2009 the Charter became binding, and the EU acceded to the UNCRPD. Moreover, until 2013 discussions took place about EU's accession to the European Convention on Human Rights. The background behind this is the rise of racism and xenophobia in the EU since the 1980s. After the populist and far-right politician Haider scored high at the Austrian general elections in 1999, the EU feared violations of human rights and started to introduce safeguards. This has triggered a reaction from all EU governments. Other concerns like the ageing of the population also explain the readiness to reform non-discrimination law, as well as the growing international attention for the rights of people living with disabilities. The rise of the combined social justice and human rights discourse in fact relates to a context of pressure in favour of the protection of human rights at the international level. At the time, we observe a multiplication of the conventions protecting several vulnerable categories (e.g. UN CEDAW, CERD, CRPD, CRC, etc.). In addition, another important factor of influence is that a majority of centre-left government representatives were sitting at the Council of Ministers at the time of the discussion of the new directives. The two 2000 directives were approved quickly, suggesting that EUMS governments felt the need to affirm and stress human rights at a time where they appeared threatened by the rise of right-wing extremisms. ${ }^{104}$ All of this adds up to a pathological lack of legitimacy of the EU integration process at the time, which made the fight against discrimination a perfect opportunity for the EU to show unity and to push forward a form of de minimis

100 Alexander Somek, Engineering Equality. An Essay on European Anti-Discrimination Law (Oxford University Press 2011), 47

${ }^{101}$ See Sandra Fredman, 'Pasts and Futures: EU Equality law' in Alan Bogg, Cathryn Costello and ACL Davies (eds), Research Handbook of European labour Law (Edward Elgar Publishing 2016)

102 See Fredman's four-dimensional model of substantive equality in Sandra Fredman, 'Substantive Equality revisited', 14 I.CON 3 (2016), 712

103 This was subsequently confirmed in Zambrano at [41] and Dereci at [62] in 2011. In Dereci, a mention of the strong link between EU and the ECHR is even made at paragraph 73, confirming the human rights approach adopted by the Court. See C-34/09 Gerardo Ruiz Zambrano v Office national de l'emploi (ONEm) EU:C:2011:124, [2011] ECR I-01177 and C256/11 Murat Dereci and Others v Bundesministerium für Inneres EU:C:2011:734, [2011] ECR 000.

${ }^{104}$ See Carlo Ruzza, 'Human rights, anti-racism, and EU advocacy coalitions' in Lydia Morris (ed), Rights: Sociological Perspectives (Routledge 2006) 
European citizenship through non-discrimination law. All these conditions hence created a favourable terrain for EU institutional actors to take action.

In addition to these historical developments, at the institutional level the human rights framing mobilised various equality activists. The directives were strongly supported by the European Parliament and the European Commission, but also the product of the mobilisation of civil society actors. For instance, several groups concerned with social exclusion were engaged in active lobbying in Brussels: The Social Platform, Solidar, the Youth Forum, the European Federation for Intercultural Learning, the European Human Rights Foundation and diverse religious organisations. ${ }^{105}$ These groups focused on various issues such as ageism and disability, but the anti-racist lobby was the most successful. The Starting Line, the Migrants' Forum, the Anti-Poverty Lobby, the Women's Lobby are examples of active partners in the dialogue with EU institutions. As early as 1993, the Starting Line Group proposed a draft directive, which later gave birth to Directive 2000/43/EC. The European Commission welcomed the civil society participation. ${ }^{106}$ The institutionalisation of new non-discrimination rights is in fact due to the match between two concerns: the globalisation of the human rights discourse on the one hand, put forward by transnational NGOs credited with legitimacy in their field; and the quest for legitimacy and exploitation of socio-political windows of opportunity by the EU institutions to serve the purpose of reviving EU integration through consensual action. Finally, the convergence between the EU and the human rights regime reflects a "dialectical tension manifest in the complex interaction between 'mobilizing' actors seeking to strengthen the institutions for human rights protection-including civil society actors, transnational networks, and supranational actors like the European Commission and the Court of Justice — and 'resistant' governmental actors seeking to curb and deter the same". ${ }^{107}$

As a result, within the Union's borders the most prominent area of human rights activity is the EU regime of antidiscrimination law, notably since the adoption of Article 13 (now Article 18 TFEU) with the Amsterdam Treaty. ${ }^{108}$ Beyond the constitutional changes operated with the Charter and the Lisbon Treaty, further reforms include the creation of a Fundamental Rights Agency replacing the Vienna monitoring centre against racism and xenophobia, and the creation of a network of experts on fundamental rights. ${ }^{109}$ However, although the 2000s were a crucial time for legislative progress in the protection from discrimination, some failures have also been observed. Digging deeper into the negotiation process of the directives, it appears that the Race Equality Directive originally arose from an effort of civil society organisations to ban race and religious discrimination and exclusion in Europe. This interfaith dialogue led to the proposal made by the Starting Line Group, which framed race and religious discrimination as a single issue, in which the two grounds are highly overlapping. ${ }^{110}$ However, when the draft was examined by the Parliament and the Commission, race was accepted as the unique ground for protection, whereas religion was later covered by Directive 2000/78/EC, with a much narrower scope. The motion towards equalising the levels of protection across grounds through the socalled Horizontal Equality Directive (the Proposal) was rejected in 2008.

While the 'fundamental rights' rationale stands until today as one of the main foundations of the European equality law project, both as a strong legitimising narrative and a legal basis to grant rights to

\footnotetext{
105 Ibid

106 The connections between civil society and the Commission have then been formalised through the creation of the recent Fundamental Rights Agency.

${ }^{107}$ De Búrca, 'The Road Not Taken: The EU as a Global Human Rights Actor', 651

${ }^{108}$ Ibid, 683

${ }^{109}$ Ibid, 671

${ }^{110}$ See Isabelle Chopin and Jan Niessen, Proposals for Legislative Measures to Combat Racism and Promote Equal Rights in the European Union (1998); Jan Niessen and Isabelle Chopin, 'The Starting Line and the Racial Equality Directive' in Niessen J and Chopin I (eds), The Development of Legal Instruments to Combat Racism in a Diverse Europe (The Development of Legal Instruments to Combat Racism in a Diverse Europe, Martinus Nijhoff Publishing 2004), 95-110 and Lilla Farkas, 'Collective actions under European anti-discrimination law' (2014) European Anti-discrimination Law Review.
} 
individuals, even in their private interactions. This reflects the rhetorical enterprise of the CJEU to enforce a human rights perspective on non-discrimination, ${ }^{111}$ coupled to a rhetoric of social justice. The language of the now failed 2008 Proposal provides a good example as it reveals an element of the 'Renewed Social Agenda: Opportunities, access and solidarity in 21st century Europe' 112 i.e. the centrality of topics of social inclusion and solidarity as the bigger aims of EU anti-discrimination policy. Presenting itself as a social justice actor and a human rights defender, strengthening equality protection has allowed the EU to access low cost legitimacy and to keep up with international standards through a facially less market-focussed logic thanks to the great purchasing power of the human rights discourse. True at the rhetorical foundational level, it nevertheless remains limited in practice by the scope of competences of EU law, which primarily concerns market-related issues.

In this context, the general principle of non-discrimination advocated by the CJEU brings equality protection closer to the standard of a fundamental right, which is associated with a higher level of protection in a wider range of situations, and for a wider range of persons than guaranteed by EU law stricto sensu. The proclamation of the general principle of non-discrimination has thus taken EU nondiscrimination law beyond its economic origins. ${ }^{113}$ Prechal speaks for instance of "a timid move from the narrow area of non-discrimination in the workplace towards issues like reconciliation of work and family life". ${ }^{114}$ This view has been confirmed by the case law and is supported by the observation that the CJEU and the ECtHR are in a loose dialogue with each other. However, the extent to which the CJEU has the competence to enforce the general principle of non-discrimination as a fundamental right is limited and not yet clear. There is an apparent tension between the universality claim born by nondiscrimination principles linked to the human rights discourse, and the limitations of the scope of EU law to the market area for most protected grounds. Hence, the focus remains strongly on market issues, mostly related to labour issues, notably after substantial backlash and worries regarding the respect of the subsidiarity principle.

\section{The hybrid EU non-discrimination model: a difficult balancing of clashing social interests}

Human rights concerns and economic integration goals constitute at the same time two competing legitimising narratives and frames of interpretation for the evolution of EU antidiscrimination law. However, today's non-discrimination rights are a construction that rely on both foundations. They relate to both the efforts to transform everyday relationships by remodelling them according to a concept of substantive equality, and at the same time to the goal of serving as de minimis safeguards in the absence of a social policy to enforce distributive equality at an EU-wide level. Reich argues for instance that, within the evolution towards fundamental rights, a social dimension developed over time, complementing the market oriented approach of EU non-discrimination law. ${ }^{115}$ That is, Article 21 and 23 of the Charter guaranteed equality as a fundamental right, the protection of which extends beyond the limited scope of employment. At the same time, the scope of EU law is limited. What space does this leave for the protection of equality beyond the market? How do both considerations play out in nondiscrimination law?

First of all, non-discrimination law is a site of balancing between two clashing social interests: on the one hand, setting societal safeguards in form of non-discrimination rights is part of guaranteeing a fundamental right to equality, and on the other hand, private autonomy of market actors is a funding

\footnotetext{
${ }^{111}$ One fairly recent example is the Test-Achats case, where the Court cites the Charter as the primary source of the nondiscrimination principle. See (nr. 38)

112 See the Proposal, (nr. 2)

${ }^{113}$ Sacha Prechal, 'Achievements and Trends in EU Gender Equality Law' (2005) <http://www.euroinfo.ee/malta/pdf/c4.pdf> accessed 10/05/2016, 13

${ }^{114}$ Ibid

${ }^{115}$ Reich, 'The Impact of the Non-Discrimination Principle on Private Autonomy', 253-254
} 
element of liberal capitalist societies. The simultaneity of a vertical and a horizontal dimension of nondiscrimination rights valid between private actors creates an "inevitable clash" ${ }^{116}$ with economic efficiency concerns and the principle of party autonomy, freedom of contract and the right to differentiate. While this clash allows to boost non-discrimination to a new level, this bipolarity of EU non-discrimination law makes the equality set of the EU, considered as a whole, resemble a "patchwork". ${ }^{117}$ In fact, the balancing between the two concerns differs across grounds and contexts, with different levels of protection, different scopes of application, and different levels of scrutiny at the CJEU.

Second, besides being criticised for its incoherence, the hybrid nature of EU equality law has been pointed at for its normative deficiency. ${ }^{118}$ Non-discrimination rights are negatively constructed. They are meant to be enforced at the individual level by corrective mechanisms, in a time of economic crisis where the maintenance of equality through comprehensive collective redistribution by a welfare state at the European level is inexistent. EU antidiscrimination law is therefore criticised for being a means to avoid costlier 'hard' measures, such as 'hard-core' social policies to be granted to entire groups positively and upstream. ${ }^{119}$ Somek for instance claims that non-discrimination law "disguise[s] the Union's lack of ability to address social concerns". ${ }^{120}$ Thus, he puts forward that antidiscrimination law in the EU often serves as an argument to justify neoliberal policies and serves as an ersatz for the unwillingness to create a European super-welfare state. Hence human rights would be a vitrine while non-discrimination law would only have the function to smoothen the interactions of different national welfare and economic systems that must cooperate within the realm of the EU. This, according to him, is meant to avoid EU member states suffering economic disadvantage in these transnational interactions. ${ }^{121}$ However, this negative model of non-discrimination rights has started to change with the shift operated towards less exclusively court-centric equality enforcement, to the advantage of a more bottom-up approach within the member states. Therefore, rather than of ersatz, one could rather speak of de minimis guarantees of protection at the national level, framed by a discursive strategy depicting equality as a global human right, but in practice limited by the market-based scope of EU competences.

While EU integration was running out of steam upon the completion of market integration, the focus on rights, notably through non-discrimination law-making, allowed the EU to regain legitimacy in its efforts towards deeper integration. The EU Commission took active steps to enhance EU antidiscrimination law to reactivate the integration process by promoting human rights as one of the core missions of the Union, and to present the EU as a protector of a pluralist society where identity claims and diversity accommodation take a more and more important place. Hence, this renewed insistence on rights and protection is both an instrument of self-legitimation and part of an effort to redefine the European model of justice in a time of crisis and austerity, within the area of competences granted to the Union.

Thus, although criticized, this hybrid model has permitted to set up common safeguards at the national levels, independently of the member states' choices in terms of social model. The consequence of this is the evolution of non-discrimination law towards diversification of equality rights, which range from economic and social to identity-related rights. This diversification relates to what Kennedy calls the "third globalization", where a discourse about identity/rights and the management of diversity through

\footnotetext{
116 Ibid

${ }^{117}$ Paiivi Johanna Neuvonen, 'Inequality in equality' in the European Union equality directives: A friend or a foe of more systematized relationships between the protected grounds?' (2015) 15 International Journal of Discrimination and the Law 222, 225

${ }^{118}$ Somek, Engineering Equality. An Essay on European Anti-Discrimination Law, 9

${ }^{119}$ Ibid

${ }^{120}$ Ibid

${ }^{121}$ Ibid
} 
human rights and non-discrimination law has succeeded to an era of the "Social". ${ }^{122}$ Kennedy argues that a global discourse of human rights and identity rights has emerged within legal systems that are bound to be pluralistic through "recognizing and managing difference" and diversity. ${ }^{123}$ EU nondiscrimination law reflects this trend through convergence with internationally promoted values and an increased protection of vulnerable identities or group memberships. Consequently, the EU model is complex and comprehends both individual liberal rights, where anti-discrimination is conceived as the equal opportunity to access the market, as well as a kind of group-based multiculturalist understanding of equality, centred on positive rights (e.g. the accommodation of diversity). The new orientation of this hybrid model is however unclear, thus casting doubts on the future of substantive equality in the EU. Yet, despite its incompleteness and apparent incoherence, the hybridity of the EU non-discrimination model can at the same time be seen as compromise between the protection of equality and of autonomy, combining recognition and distribution by focusing on the encompassing access to market participation as a pre-condition for citizenship in the Union.

\section{Non-discrimination as a site of reconciliation: equal citizenship through market participation}

In this perspective, instead of opposing the economic and the rights-based understandings of equality, both can be brought together within the logic of substantive equality and the transformative endeavour of the EU. In order to reconcile the tension between the extension of EU non-discrimination law towards the protection of diversity, identity and human rights as a general principle on the one hand, and on the other the predominantly economic bound of non-discrimination rights, it is useful to think about the diverse dimensions of equality. In fact, both distribution and recognition are two fundamental aspects of equality. Both dimensions are key to social participation, and thus citizenship. If we accept Fredman's definition of equality as full participation, equality encompasses four dimensions: political participation, economic participation and the redress of disadvantage, identity recognition and accommodation of diversity, and finally the end of violence and stigma. ${ }^{124}$ The recent change of rationale in EU nondiscrimination law seems to have extended the scope of protection from the second dimension (economic) to the third (identity recognition and accommodation), and even to some extent the fourth, within the limit of the scope of EU law. ${ }^{125}$ Hence, the hybrid transformation of EU equality law as both a safeguard for economic participation (labour, consumption) and an expression of the fundamental right to equality can be understood as a project to give vulnerable EU citizens the possibility to fully participate within EU society.

Equality through the market: granting participation of socially marginalised groups through distribution

An optimistic understanding of the evolution of EU non-discrimination law is to consider the market focus as a condition for equality. Therefore, one can speak about distribution as a form of equality happening in the framework of the market, by opposition to redistribution, which, despite also being a social equaliser, is a form of post-market equality promotion. In fact, the market is one of the main sources of social interactions in life, through labour and consumption. It is also an area over which the EU has regulatory powers, as opposed to other areas like family law where European non-discrimination laws have no grasp. By way of illustration, the Lisbon Strategy had at its heart this idea that antidiscrimination law should serve to boost competitiveness and to reconcile solidarity and economic efficiency. Antidiscrimination law as a corrective to unbalanced social and market opportunities is based

\footnotetext{
${ }^{122}$ Duncan Kennedy, 'Three Globalizations of Law and Legal Thought: 1850-2000' (2006) 19 The New Law and Economic Development

${ }^{123}$ Ibid, 65

${ }^{124}$ See Sandra Fredman, 'Substantive equality revisited' (2016) 14 International Journal of Constitutional Law 712 . This is based notably based on Susan Sturm's work on 'full participation'.

${ }^{125}$ For instance, the EU has adopted criminal law provisions as means against racial discrimination and violence. The first dimension is out of the scope of non-discrimination law.
} 
on the assumption that virtually all human interactions are market interactions, and that inequalities can be remedied on an individual basis. ${ }^{126}$ This is why, according to this liberal understanding, "[i]t is difficult to imagine a principle that would be better suited to reconciling solidarity and competitiveness than the principle of equality of opportunity". ${ }^{127}$ Access to the market ensures economic, and therefore a form of social, participation through labour and the access to goods and services. Hence, it constitutes a precondition for full participation in society, which is a core dimension of equality. Münch describes this process as the "premarket activation" of each individual and "the guarantee of equal opportunity" instead of "postmarket redistribution with the aim of approaching an equality of results". ${ }^{128}$ This means abolishing discrimination as an obstacle to the limitation of the participation of these minorities in the EU (economic) project. This form of "access justice" ${ }^{129}$ seems to reconcile the tension between imperative and instrumental framings of equality, by conceiving of antidiscrimination law as an equaliser in private relations and thus in social participation. Non-discrimination and equality rights in fact serve to protect "weaker parties" 130 or citizens made vulnerable by their membership in socially disadvantaged groups, that must be protected and accommodated. ${ }^{131}$ According to Micklitz, EU nondiscrimination rules provide workers and consumers with the bundle of rights necessary for them to be able to participate in and to gain from the EU economy. ${ }^{132}$ Equality of opportunities in "reaping off the benefits of the market" 133 is a pre-condition for exercising freedom and citizenship in the EU. Of course, this is a liberal and economically driven understanding of equality, just like the Union itself. In this perspective, protecting EU citizens horizontally from discrimination mainly means granting them access to publicly and privately provided goods and services (as diverse as housing, health, etc.), and the labour market. This anchor in the market stems from the very range of competences of the EU. If the transformative bite of non-discrimination law mainly affects employment and consumption, rather than for instance marriage law, ${ }^{134}$ it is indeed because of the nature and powers of the EU.

However, this form of "access justice" 135 cannot be equated with a redistributive dimension of equality. At most, it is a bridging principle at the EU level that calls for complementary social redistributive measures at the national level, the determinacy of which is left in the hands of national governments. In fact, beyond market rights, only a few other domains are regulated by non-discrimination law, but the unbalance in favour of market related areas is important. Still, in light of the prevalently economic competences of the EU, these guarantees constitute crucial minimum standards. As a consequence, even though seen in opposition, the rights narrative and the market narratives are not contradictory. They both contribute to the transformative function of EU non-discrimination law, through an attempt to grant substantive participation opportunities to all citizens, by protecting the ones society's power structures make vulnerable, but with a focus on market access, domain of competence of the EU. This can be equated with a logic of equality of opportunities. Therefore, it can be for being unable to ensure a form of equality of results, which would require redistributive elements. Yet, some complementary efforts such as affirmative action and accommodation push forward a less formal and a more substantive vision of equality. In this, the protection of the access to the market is nevertheless limited to some characteristics which correspond to ascriptive identity traits, and leaves out social or family status,

\footnotetext{
${ }^{126}$ Somek, Engineering Equality. An Essay on European Anti-Discrimination Law, 15

${ }^{127}$ Ibid, 3

${ }^{128}$ Ibid, 151

${ }^{129}$ See Hans Micklitz, 'Social justice and Access Justice in Private Law', (Working Paper, European University Institute 2011)

${ }^{130}$ Ibid, 21

${ }^{131}$ Reich speaks of "vulnerable consumers" but this formulation seems a bit essentialising. See Reich, 'The Impact of the NonDiscrimination Principle on Private Autonomy', 270.

${ }^{132}$ Micklitz, 'Social justice and Access Justice in Private Law, 23

${ }^{133}$ See ibid

${ }^{134}$ De Búrca, 'The Trajectories of European and American Antidiscrimination Law', 14

${ }^{135}$ Ibid
} 
income, etc. An open question regards whether the Union is willing to go so far in its access justice logic as to use the Charter as a touchstone for non-discrimination and equality, ${ }^{136}$ which would basically correspond to the full enforcement of a general equality principle across a broader range of categories. ${ }^{137}$ Looking at the current unevenness of equal protection casts doubts on this perspective and supports more the differentiated protection hypothesis. However, here one of the key dimensions of equality clearly appears: recognition.

Equality before the market: recognising identity, accommodating diversity

Looking at the EU non-discrimination system from the point of view of participation reveals another dimension. Granting market access to vulnerable groups or individuals also comprehends a dimension linked to identity recognition of marginalised or vulnerable groups. Münch argues that the removal of market barriers only helps the active and leaves the inactive even more marginalised, so that targeted policies are designed to support them and grant them access to the market. ${ }^{138}$ According to him, market integration is now completed because barriers of (economic) discrimination have been removed so that the market-driven dimensions of non-discrimination law are now overridden by concerns over inclusion and recognition. ${ }^{139}$ As he puts it, "the collectively shared identity of minorities was left as the last reason for discrimination". ${ }^{140}$ Therefore, the other dimension of participation is recognition. In fact, EU nondiscrimination law and policy places much weight on the recognition of discriminated identity traits and the accommodation of diversity. As constitutional liberalism has created equal opportunities for the members of the dominant culture, demands for recognition of other cultural identities is rising. Therefore the question of the replacement of constitutional liberalism by constitutional multiculturalism arises, which would also protect "the cultural identities of groups" in addition to the "individuals' rights to freedom". ${ }^{141}$ It reinforces the position of all - and therefore of (some of the) disadvantaged - EU citizens as workers and consumers through a strengthening of their individual rights but also as groups sharing the same identity characteristics.

All in all, even if at first there seems to exist a liberation move of non-discrimination law from the economic logic, recognition and distribution are intrinsically connected. Recognition is actually rendered possible through targeted measured aimed at improving economic opportunities of some particular groups. Therefore, while the rights-driven and the economic-driven projects seem in contradiction at the rhetorical level in the task of legitimising narrative for EU non-discrimination law; looking at the application of EU non-discrimination law makes clear that both logics work in sync. In the absence of a proper redistributive dimension in the EU social project, non-discrimination rights serve the protection and the recognition of diverse identities through guaranteeing their participation in EU citizenship, which is primarily constituted by market participation, the four basic freedoms and their derivations. The logic behind EU non-discrimination law is a liberal polity that solves social conflicts by promoting economic growth, individual freedom and individual access to markets. Yet, in the very selection of identities to protect, recognition generates a collective dimension within a very individual equality model.

\footnotetext{
${ }^{136}$ Micklitz, 'Social justice and Access Justice in Private Law, 18

${ }^{137}$ In fact, the Charter includes 15 categories in its Article 21: language, social origin, genetic features, birth, property, political and other opinion, national minorities, sexual orientation, disability, gender, race and ethnic origin, religion and age.

${ }^{138}$ Münch proceeds with a view of the EU polity as a structure of "acquisitive individualism" where the main focus is "each individual's access to the market, and the improvement of his or her position in the market". See Münch, European governmentality: the liberal drift of multilevel governance, 142-143

${ }^{139} \mathrm{Ibid}$

${ }^{140}$ Ibid

${ }^{141}$ Ibid
} 
However, the argument that granting market access to these minorities has become the centre of the non-discrimination law because no other form of inclusion is recognised can be challenged. Some elements in the present directives, as well as in the project for their horizontal extension, show that the fight against discrimination goes beyond the sole, albeit central, access to the market. Reich argues that promoting EU citizenship through anti-discrimination law departs from an individualistic concept of equality and evolves towards an understanding of its collective dimension. ${ }^{142}$ Yet this is minimalistic and does not correspond to the definition of group justice as focusing on redistribution and "redress[ing] past subordination and discrimination". ${ }^{143}$ For instance, the recent prohibition of indirect discrimination relates more to the collective nature of discrimination than direct discrimination, which is more centred on individuals. For a long time, the discussion on the collective effects of discrimination has largely been undermined by an omnipresent individualistic focus, explainable because of the predominant enforcement structure through individual claims in front of the CJEU. This has started to change with the missions given to the equality bodies. The administrative turn, more centred on policy recommendations, awareness-rising work and enforcement tries to address this bias by diffusing equality at all levels in the EU member states. This is all the more noticeable that often the mandates of equality bodies go beyond the minimum standards guaranteed by the EU. The promotion of social inclusion therefore goes beyond a liberal individualistic conception of justice and is also associated with grouporiented justice, ${ }^{144}$ in dialogue with social groups themselves. The EU Commission in fact stands in continuous exchange with civil society and advocacy groups, as well as with researchers and the academia in order to advance equality protection. Beyond the market access and rudimentary "welfarist" 145 dimensions, EU non-discrimination law also includes aspects linked to genuine recognition. Identity recognition politics in the form of non-discrimination laws can however be criticised for complying with the neoliberal requirements of limiting the use of redistributive justice as a remedy against inequality ${ }^{146}$. In fact, the EU has only the power to guarantee the access to the market to 'vulnerable' categories, not participation itself.

\section{Equality beyond the market: non-discrimination through citizenship}

Some elements in the recognition of the groups protected by non-discrimination law and the nature of this protection go beyond market concerns and touch upon other important dimension of substantive equality. Elements of protection linked to dignity or dimensions of social participation and inclusion other than economic, such as education and social protection, are in fact not subsumable in the category of market access rights, even though the latter stay at the centre of EU non-discrimination law. Prechal herself notices "a shift away from the economic integration motives towards the recognition of equality and non-discrimination as a self-standing fundamental right". ${ }^{147}$ Other commentators spoke, as early as 2002, of a new guiding rationale in EU non-discrimination law, with concepts like "fairness, autonomy, human dignity and respect for human rights" as well as "the creation of a better society" as leitmotivs. ${ }^{148}$ Looking at EU non-discrimination law from the point of view of citizenship explains both the market access and the dignity-based or recognition-based rights as necessary and complementary dimensions

\footnotetext{
${ }^{142}$ Reich, 'The Impact of the Non-Discrimination Principle on Private Autonomy'

${ }^{143}$ See Christopher McCrudden, 'Thinking about the discrimination directives' (2005) 1 European Anti-discrimination Law Review 17 and Sandra Fredman, 'Double trouble: multiple discrimination and EU law' (2005) 2 European Antidiscrimination Law Review 13, 18

${ }^{144}$ Reich, 'The Impact of the Non-Discrimination Principle on Private Autonomy', 275

${ }^{145}$ See Reich, 'The Impact of the Non-Discrimination Principle on Private Autonomy'. This is for instance non-discrimination as regards social protection.

${ }^{146}$ See Nancy Fraser, 'Rethinking recognition' (2000) 3 New Left Review

${ }^{147}$ Prechal, 'Discrimination does not fall down from heaven': the context and evolution of non-discrimination in EU law, 8

${ }^{148}$ Evelyn Ellis, 'The principle of non-discrimination in the Post-Nice Era', in Arnull and Wincott (Eds.), Accountability and Legitimacy in the European Union (Oxford 2002), 293 quoted in Prechal, 'Discrimination does not fall down from heaven': the context and evolution of non-discrimination in EU law, 8
} 
of equality. Full participation in society is a key condition of equal citizenship. Protecting equal citizenship through non-discrimination law is a way to further integration, in which the EU performs two tasks. On the one hand, it protects citizens from institutional discrimination at the level of member states. On the other hand, it constructs a more equal transnational society where all member states must enforce minimum standards and where the EU is the last guardian of these minimum equality norms. ${ }^{149}$ By transforming EU citizenship and integrating the levelling dimension of equality, the EU seeks to change citizens' interrelationships in several key areas of social life, but within the limits of the scope of EU law. This does not only concern market participation and its direct consequences in terms of social relations, but also - although for certain grounds only - education, social benefits, health, the media, etc. ${ }^{150}$ This transformative understanding goes further than what an equal access to the market. According to Reich, the anti-discrimination principle protects the "autonomy of persons as EU citizens to enjoy a bundle of rights, in particular the right to free movement in a broader sense". ${ }^{151}$ Therefore, equality is a core dimension of EU citizenship, in all areas where the EU can potentially intervene. In this perspective, the protection from racial discrimination goes the furthest, even blurring the frontier of EU competences to a certain extent, which might be a cause for the lack of extension of such an extensive protection from discrimination to other grounds.

Thus, non-discrimination is now one of the constituting principles of private law in EU law, "creeping into European contract law", and even has the potential to expand its scope of application beyond areas and grounds so far recognised. ${ }^{152}$

However, until today equality in the EU is mainly realised through the equal access to the labour, goods and services markets. While a model of access justice is prevalent, a more comprehensive version of equality oriented towards a collective justice beyond market also exists. A major problem is that it is currently limited to the grounds of gender and race. The proposal to extend this comprehensive protection to the other protected grounds has failed, thus creating a long-term hierarchy between the grounds protected, with different standards, material scopes and approaches. This differentiated protection is at odds with the rising general principle of equal treatment proclaimed by the Court and backed by the institutional language of a fundamental right to equality.

\section{Hierarchies in EU non-discrimination law: a differentiated equality protection}

Since its origins, EU non-discrimination law is characterised by a differentiated equality protection. Anti-discriminatory provisions on grounds of nationality and sex were introduced first. They remained the only protected vectors of discrimination for more than 40 years. With the introduction of a multiple grounds approach in 2000, one would have expected the protection to extend uniformly across all legislated grounds. However, the EU non-discrimination system is fractured by several lines of hierarchy. The argument of this section is that a double de jure and de facto hierarchy limits the potential and reach of the newly promoted general principle of non-discrimination, both as market access and as a fundamental right. This double hierarchy poses limits to the transformative reach of the general principle of non-discrimination in the EU. Besides, the fact that it results from contingent individual reforms instead of a systemic politically reflected and socially conscious choice poses problems in terms of values and prioritisation of protection.

\footnotetext{
${ }^{149}$ See the distinction made in Muir, 'The Transformative Function of EU Equality Law'

${ }^{150}$ See (nr. 1)

${ }^{151}$ Reich, 'The Impact of the Non-Discrimination Principle on Private Autonomy', 260

152 Ibid, 271
} 


\section{De jure hierarchy}

The first place in which hierarchy fractures the EU non-discrimination system is the legislative setting. A de jure hierarchy has been established by the three new directives 2000/43/EC, 2000/78/EC and 2004/113/EC. This is true at three levels: the scope, the exceptions and the effectiveness of secondary legislation.

\section{Scope of protection}

First, the scope of protection of each ground is different. Racial and ethnic discrimination is prohibited in several areas: in the field of employment, including self-employment, occupation and vocational training; in the field of education; in the field of social protection (social security and health care) and social advantages; and in the field of access to and supply of goods and services available to the public, including housing. These prohibitions are guaranteed by Directive 2000/43/EC, which features the broadest scope of protection among all protected grounds of discrimination. Gender discrimination has historically been prohibited in the field of employment, where EU non-discrimination law has its roots. Indeed, secondary rules guarantee equal pay since 1975 with the first Equal Pay Directive ${ }^{153}$ and equal treatment since 1976 with the so-called second Equal Treatment Directive. ${ }^{154}$ The principle of equal treatment between men and women was furthered and completed by directives in the fields of statutory social security, ${ }^{155}$ occupational social security schemes, self-employment, pregnant workers and parental leave from the 1970s to the 1990s. Many of these provisions have been clarified, modernised and harmonised by Recast Directive 2006/54. ${ }^{156}$ In between, a major extension of gender equality protection took place in 2000 with the enactment of Directive 2004/113/EC prohibiting discrimination in the access to and supply of goods and services. ${ }^{157}$ In addition, EU law proclaims the principle of gender mainstreaming, which means that gender issues must be put at the centre of every policy, independently of which are of law/policy is concerned. As a result, race and gender equality are very broadly protected, notably in two major life areas, that is employment and consumption. However, we already notice the existence of a de jure hierarchy between the protection against racial and sex-based discrimination. While the Race Equality Directive includes education in its scope, gender equality protection explicitly leaves education out, as well as the media and advertising. ${ }^{158}$ All the other grounds protected are the product of the guarantees laid out in Directive 2000/78/EC. The so-called Framework Equality Directive protects religion or belief, sexual orientation, age and disability in the area of employment, including vocational training, self-employment, education, and covering working conditions (pay, dismissals, promotion). The protection explicitly excludes state-based social protection, including social security. ${ }^{159}$ It also excludes education as well as the field of consumption of goods and services. This makes the level of protection of the four latter grounds the most reductive across the entire EU non-discrimination field.

The EU non-discrimination secondary law: a hierarchy based on scopes of protection ${ }^{\mathbf{1 6 0}}$

\footnotetext{
${ }^{153}$ Council Directive 75/117/EEC of 10 February 1975 on the approximation of the laws of the Member States relating to the application of the principle of equal pay for men and women [1975] OJ L45/19

${ }^{154}$ Directive 76/207/EEC, see (nr. 12)

${ }^{155}$ Council Directive 79/7/EEC of 19 December 1978 on the progressive implementation of the principle of equal treatment for men and women in matters of social security [1978] OJ L6/24

${ }^{156}$ Directive 2006/54/EC, see (nr. 1)

${ }^{157}$ Directive 2004/113/EC, see (nr. 1)

${ }^{158}$ See Article 3 of Directive 2004/113/EC, and more particularly Article 3 para. 3. See (nr. 1)

${ }^{159}$ See Article 3 para. 3 of Directive 2000/78/EC. See (nr. 1)

${ }^{160}$ Nationality has been excluded from the classification because it is only protected by Article 18 of the TFEU, and by secondary law only in the area of free movement of persons by Directive 2004/38/EC. It is explicitly excluded by all other non-discrimination directives.
} 


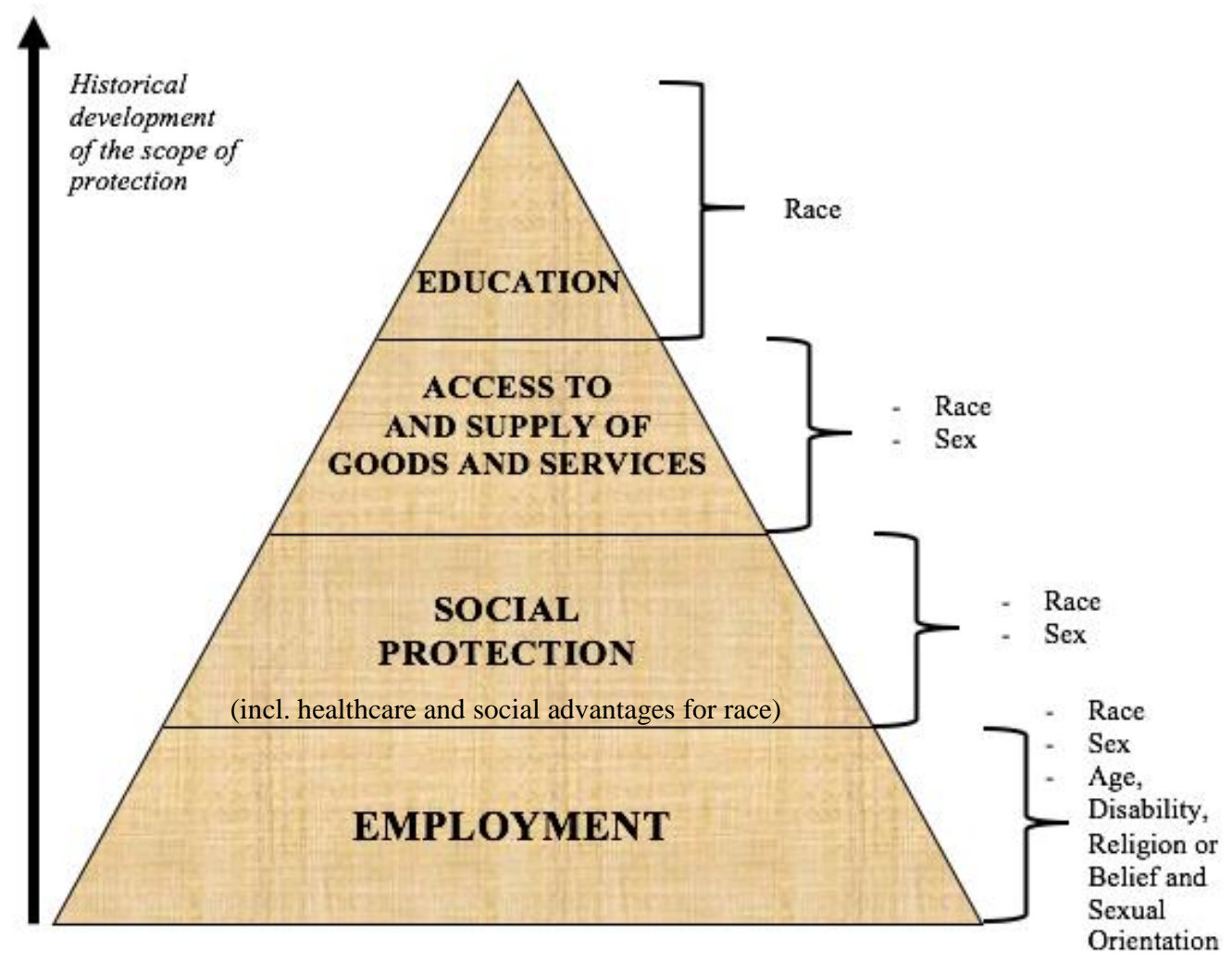

For what concerns the material scope, only gender, and to a certain extent race, are protected beyond the market (e.g. in social protection and health care for race and gender and in education for race only). Within the market, they are also protected to a larger extent than the other grounds (consumption of goods and services instead of employment contexts only). This means that race and gender are protected horizontally, that is not only in public-private relationships involving the State, but also in relations between private actors within the public domain (commercial or professional activities), not only in the employment context, but also beyond, contrarily to other grounds. The proposal made by the European Commission in 2008 to extend the material scope of protection of the other grounds outside the labour market to the consumption market, education and social protection was a failure. ${ }^{161}$ In parallel, the Commission planned to amend Directive 2000/43/EC by extending positive action, reasonable accommodation and remedial provisions in the field of racial discrimination. This attempt failed as well. One more piece of evidence of this hierarchical ordering is that the creation of equality bodies is only an obligation in the fields of gender and race equality, not for the other grounds protected by the Framework Equality Directive. The requirement that these organisations support applicants and act on their behalf in judicial proceedings ${ }^{162}$ therefore only compulsorily applies to race and gender, thus extending the hierarchy to enforcement. Finally, the fact that secondary legislation only protects some of the characteristics protected by Article 21 of the Charter also indicates a hierarchy. While the Charter additionally protects language, social origin, genetic features, birth, property, political and other opinion and national minorities, the most recent non-discrimination directives remain silent in this regard.

\section{Legislative exceptions}

The second place in which a hierarchy is distinguishable is the list of exceptions provided for each ground in the directives. Apart from the general exception of genuine occupational requirement which,

\footnotetext{
${ }^{161}$ See (nr. 2)

${ }^{162}$ Craig and De Búrca, 'Equal Treatment and Non-Discrimination', 911
} 
in very rare instances, authorises differential treatment based on a protected ground, discrimination based on certain grounds is more easily justifiable than on others. Indeed, the Framework Equality Directive foresees in its recital 19 that the non-discrimination provisions may not apply to the armed force for the grounds of disability and age. Article 4(2) of Directive 2000/78/EC provides for exceptions for religious institutions, which can impose certain conditions on their employees, mainly on the basis of their sex. ${ }^{163}$ Further, Recital 25 and Article 6 of Directive 2000/78/EC provide for specific derogations linked to age when differential treatment is justified, thus lowering the level of protection against age discrimination in comparison to other grounds. ${ }^{164}$ In Article 6, the exceptions to the prohibition of age discrimination take the form of objective and reasonable 'justifications' of differential treatment, which must serve a legitimate aim. However, the provision is wide and the high number of possible justifications has yielded many referrals to the CJEU, in fact the highest among all grounds. Usually justifications only apply to indirect discrimination and not to cases of direct discrimination, but in the case of the justifications of differential treatment based on age, the directive does not specify. Hence, direct as well as indirect discrimination can be justified by the list of exceptions provided in Article 6 of Directive 2000/78/EC. The CJEU is therefore left with important discretion in its interpretation of the justifications, and its case law has shown a wide margin of application let to the member states.${ }^{165}$ Besides, the protection of national origin is restricted by Directive 2000/43/EC so as to respect member states' power to control immigration at their borders. However, some concerns have been expressed that this exception might deal as a limitation of the protection from racial discrimination for third-country nationals. ${ }^{166}$ The sum of these different exceptions contributes to the fragmentation of the nondiscrimination protection. By providing certain derogations or justifications based on certain grounds but not others, it reinforces the existence of a de jure hierarchy.

\section{Effectiveness}

The third place in which hierarchy operates is the effectiveness ${ }^{167}$ of the non-discrimination legislation, which is related both to the source of law and to the judicial interpretation of the relevant provisions. Originally, the prohibition of sex discrimination has been anchored in the Treaty (Article 119 EC regarding equal pay, now Article 157 TFEU). In Defrenne II, the Court confirmed that the Treaty anchor gave horizontal direct effect to the principle of sex equality in the context of employment. The prohibition of discrimination on grounds of nationality also benefitted from a limited horizontal direct effect under certain circumstances. ${ }^{168}$ This is explained by the existence of a general principle of nondiscrimination on the ground of nationality, linked to Article 18 TFEU. In fact, in Marshall ${ }^{169}$ the CJEU made clear that there is no horizontal direct effect ensuing from directives. Recently, the Court revived

\footnotetext{
${ }^{163}$ So far no case of discrimination by a religious institution on the basis of sexual orientation has been referred to the CJEU.

${ }^{164}$ Recital 25 of Directive 2000/78/EC reads "[t]he prohibition of age discrimination is an essential part of meeting the aims set out in the Employment Guidelines and encouraging diversity in the workforce. However, differences in treatment in connection with age may be justified under certain circumstances and therefore require specific provisions which may vary in accordance with the situation in Member States. It is therefore essential to distinguish between differences in treatment which are justified, in particular by legitimate employment policy, labour market and vocational training objectives, and discrimination which must be prohibited." Article 6 deals with the "[j] ustification of differences of treatment on grounds of age". See (nr.1)

${ }^{165}$ Evelyn Ellis and Philippa Watson, 'Exceptions to the non-discrimination principle' in Piet Eeckhout and David Anderson (eds), EU Anti-Discrimination Law (Oxford University Press 2012), 408-409 and 416.

166 Ibid, 401

${ }^{167}$ See Mangold [68] at (nr. 35) and Gráinne De Búrca, A hierarchy of equalities (NYU Law 2016)

${ }^{168}$ Mirjam De Mol, 'The Novel Approach of the CJEU on the Horizontal Direct Effect of the EU Principle of NonDiscrimination: (Unbridled) Expansionism of EU Law?' (2011) 18 Maastricht Journal of European and Comparative Law $109,115-117$

${ }^{169}$ Case-152/84 M. H. Marshall v Southampton and South-West Hampshire Area Health Authority (Teaching) EU:C:1986:84, [1986] ECR I-04367
} 
the debate by deriving a horizontal direct effect from the general principle of non-discrimination on grounds of age underpinning Directive 2000/78/EC. This first happened in Mangold, where the CJEU gave validity to the general principle even though the transposition time of the directive had not yet passed. Precisely because of the finding of this general principle, the CJEU could later confirm its horizontal direct effect in Kücükdeveci, and more recently in Dansk Industri. ${ }^{170}$ The novelty is that the general principle at stake generates horizontal direct effect without being a written source of EU law, ${ }^{171}$ as previously the case for sex and nationality with Treaty provisions, but rather a finding of the Court itself through its case law. Given its level of abstraction, this is an important innovation for the principle of effectiveness in EU non-discrimination law. ${ }^{172}$ As a result, questions arise regarding the material scope of the new general principle of non-discrimination and its extension to other grounds also protected by Directive 2000/78/EC, as well as its effectiveness. By posing the hypothesis that this general principle could be developed given the high amount of age discrimination litigation in front of the Court, one can wonder whether the same approach will be extended to other grounds when opportunities to do so increase through a higher amount of litigation on the new grounds. The case of Römer, where the CJEU invoked the general principle of non-discrimination on grounds of sexual orientation, seems to indicate so, as the Court implied that the principle would cover all grounds protected by Directive 2000/78/EC. ${ }^{173}$ Since the apparition of the general principle of nondiscrimination, the question of the link between the EU human rights order, the European Charter of Fundamental Rights but more largely the European Convention on Human Rights, and the EU nondiscrimination regime is more vivid than ever before. The question of equality as a Treaty provision and as a human right contained in the Charter, which as constitutional status since 2009, seems to develop an existence beyond the EU statutory non-discrimination apparatus. In fact, the "new and distinctive substantive discrimination architecture" 174 identified by Kilpatrick might well be extended to the newly protected grounds, expanding the general principle of non-discrimination and its wide reach, posing the question of its material scope, effectiveness and limits. This would make the protection of the new grounds very different from the protection frameworks of gender and race, which have been developed separately and through different instruments. However, some common points exist, as gender and nationality (in a limited way) benefit from a horizontal direct effect, while the CJEU also recognised the existence of a general principle of non-discrimination on grounds of race, arising from Article 21 of the Charter, in Belov. ${ }^{175}$ Nevertheless, until today the principle of effectiveness has mainly contributed to the creation of another line of hierarchy within the EU non-discrimination regime, with horizontal direct effect for the general principle of non-discrimination on grounds of age and for sexual orientation (although through a much timider approach), as well as for gender equality and in a more limited way for non-discrimination based on nationality. The prohibition of discrimination based on other grounds such as religion and disability do not (yet) benefit from the same horizontal direct effects. This might also be explainable by the still relatively low amount of litigation on these three grounds, as well as the timid development of the horizontal direct effects framework for sexual orientation.

This de jure triple hierarchy arises from the existence of different material scopes for the different grounds protected, from the existence of more or less numerous exceptions according to the ground concerned, and from the different levels of effectiveness associated to the protected grounds according to their different legislative setting. This has given rise to an uneven protection, with a scale of grounds

\footnotetext{
${ }^{170}$ C-441/14 Dansk Industri (DI) contre Succession Karsten Eigil Rasmussen EU:C:2016:278, [2016]

${ }^{171}$ De Mol, 'The Novel Approach of the CJEU on the Horizontal Direct Effect of the EU Principle of Non-Discrimination: (Unbridled) Expansionism of EU Law?', 119

${ }^{172}$ In fact, so far only regulations as well as Treaty provisions and provisions of directives that are precise enough could generate direct effect. See Case-26/62 Van Gend en Loos v Nederlandse Administratie der Belastingen [1963] EU:C:1963:1

${ }^{173}$ Kilpatrick, 'The Court of Justice and Labour Law in 2010: A New EU Discrimination Law Architecture', 287. See also Mangold [56]-[60]

${ }^{174} \mathrm{Ibid}, 282-283$

${ }^{175}$ C-394/11 Valeri Hariev Belov v CHEZ Elektro Balgaria AD and Others EU:C:2013:48, [2013]
} 
which features race on top, gender second, age at the bottom, and religion, sexual orientation and disability in the third position. This de jure hierarchy is completed by a de facto hierarchy.

\section{De facto hierarchy}

Even though not inscribed in the law itself, this de facto hierarchy is discernible at several levels. In addition to upholding many of the legal justifications made possible by the various directives, the CJEU has also applied different levels of scrutiny to the diverse protected grounds, leading to differentiated equality guarantees. Finally, the amounts of litigation and referrals to the CJEU differ from ground to ground, thus influencing the development and the level of protection of the grounds concerned.

Implementation of exceptions, justifications, remedies and levels of scrutiny by the CJEU

The first site in which this de facto hierarchy expresses itself is the interpretation given by the Court in terms of scrutiny of, and justifications for, differential treatment. One way to explain the variations in the application of justifications and level of scrutiny is to look at the rationales underlying the protection of the grounds. This induces variations of judicial interpretations of the protection against discrimination.

First, this de facto hierarchy expresses itself through the implementation by the CJEU of the exceptions and justifications contained in the directives. As a 'newer' and 'special' ground, age bears a qualitatively different load than other discrimination grounds (changing according to time and space, and to be experienced by everyone of us). At the same time, age seems to be a less controversial ${ }^{176}$ ground so that the CJEU finds it easier to contradict age-based national and private policies. This is why the Court applied a looser standard of scrutiny in the age discrimination cases, sometimes considering differential treatment as a proportionate measure serving legitimate aims. ${ }^{177}$ It follows that the Court has adopted a mixed approach to age discrimination, considering differential treatment on grounds of age as more acceptably justified because of its mutable nature and its strong economic bearing, but also as an easier basis for intervention in national policies compared to more controversial grounds such as religion or sexual orientation.

The hierarchy of grounds is also visible when one observes the remedies granted to victims. For instance, direct gender-based and race-based direct discrimination do not bear any possible justification, while all other grounds can be justified by public order concerns. Some commentators argue that the difference in protection of the various grounds reflects differences in the meaning of equality, ranging from redistribution, to identity recognition and participation. More precisely, these variations in the legal provisions, material scope, specificities and remedies associated to each ground put in competition these different meanings of equality. In parallel to this, the recognition of identity diversity presents itself as already a form of equality guarantee, in the sense of a public acknowledgement of the existence and legitimacy of certain minorities. ${ }^{178}$ Finally, participation is perceived as equality so far as social dialogue and political participation give people equal opportunities to shape and exploit their own life chances. ${ }^{179}$ This creates further tension and conflict in the implementation of the new directives, as there is no

\footnotetext{
176 This is compared to other grounds of which the protection is much more societally contested. One concrete example could be the protection from discrimination based on sexual orientation in the French context of the protests linked to the 'mariage pour tous' reforms, or the agitation following the so-called gay cake decision. Gareth Lee v Colin McArthur, Karen McArthur and Ashers Baking Company Limited [2016] NICA 39

${ }^{177}$ See Kilpatrick, 'The Court of Justice and Labour Law in 2010: A New EU Discrimination Law Architecture' for an analysis of the more expansive justification approach adopted by the Court through a mix of balancing and justification elements in its age discrimination case law.

178 This type of recognition happens at the symbolical level, which is often important in equality protection issues. However, critiques have pointed at identity recognition as a low-cost solution to avoid granting redistributive remedies to redress inequality, in sync with the predominant neoliberal context.

${ }^{179}$ See McCrudden, 'Thinking about the discrimination directives'
} 
possible one-size-fits-all model but different approaches, specific to each type of ground. Instead these grounds and their associated equality model often clash and a prioritisation needs to be made. The CJEU jurisprudence shows that the Court oscillates between all these considerations, putting emphasis on one or the other aspects, but often quite inconsistently.

The third site in which one can distinguish a de facto hierarchy is the differences in scrutiny applied by the Court. "[B]alancing seemingly contradicting principles of autonomy and non-discrimination" is a relative task ${ }^{180}$ because the balancing exercise performed by the Court depends on the area of law and the ground concerned. ${ }^{181}$ This hierarchy broadly corresponds to the US logic of the so-called 'suspect classifications', even though jurisprudential differential treatment is not strictly coded as in the US, but only impacts the level of scrutiny, whereby not as consistently as in the US. Prechal holds for instance that "the different rationales [underlying non-discrimination legislation and the different protected grounds] not only influence the interpretation and application of the various concepts of equality and non- discrimination, [but] also influence their mutual relationship" ${ }^{182}$ While the level of scrutiny applied is dependent on the predominant rationale underlying the legislative protection at stake, the CJEU also tends to read economic interests in light of the fundamental rights understanding of equality and vice versa. This complicates the reading of the scrutiny scale applied by the CJEU, and renders impossible to automatically infer from the rationale underlying the protection of the ground at stake the strictness of review that is going to be applied. First, rationales matter at two levels: the context, circumstances or area in which non-discrimination legislation is applied, and second the protected ground concerned. Regarding the context and circumstances, Prechal claims that a looser test is applied in social security or taxation compared to employment or pay discrimination, at least in the case of gender. ${ }^{183}$ In the case of variations according to protected grounds, some features can be distinguished. For instance, Prechal makes clear that the review standard for nationality cases is very strict. We can suppose that this is because of the historical nature of the protection, and because non-discrimination on grounds of nationality stood as a sine qua non condition for the then under construction Single Market. For age cases, however, the level of scrutiny seems looser given all the justifications mentioned earlier, and the recent and special nature of the ground of age, both a mutable trait and associated with economic rather than fundamental rights considerations. ${ }^{184}$ As regards grounds banned under a fundamental rights rationale, such as race and disability, the standard of scrutiny seems to have been stricter, with a balance struck in favour of fundamental rights rather than competing economic interests. ${ }^{185}$ This reflects the dominant discourse about fundamental equality rights at the international level. As a historical mixed ground, gender equality enjoys both the functional protection linked to its economic consequences for the Single Market, and the more recently acquired fundamental right status recognised at the international level. This might however not be the case for religion, despite its international protection as a prohibited ground for discrimination at the UN and Council of Europe level. In fact, in the absence of a strong consensus on the place of religion in society within the EU, and in a context of both rising islamophobia and politicisation of the religious question in European societies (especially as regards Islam), it is unlikely that the CJEU expresses strong views on religious freedom, especially in a country like France, where laïcité presented as a neutral attitude from the State vis a vis religion deals as a way to exclude Islam from the public sphere. ${ }^{186}$ Likewise, the decisions in Achbita and Bougnaoui rather

\footnotetext{
${ }^{180}$ Reich, 'The Impact of the Non-Discrimination Principle on Private Autonomy', 256

${ }^{181}$ See also Kilpatrick, 'The Court of Justice and Labour Law in 2010: A New EU Discrimination Law Architecture'

182 Prechal, 'Discrimination does not fall down from heaven': the context and evolution of non-discrimination in EU law, 11

183 Ibid

${ }^{184}$ This does not exclude some cases where strict scrutiny has prevailed, such as the Age Concern England case, despite the considerable leeway left to the Court under Article 6(1) of the Framework Directive.

${ }^{185}$ See Römer [59]-[60], see (nr. 47)

${ }^{186}$ E.g. the debate about burkini in France during summer 2016.
}

This is especially problematic since the idea behind the Race Equality Directive originally included religion but this was rejected at a later stage of the negotiations. 
indicate restraint in a context of high political sensitivity, both having trait to sovereignty and cultural identity questions. ${ }^{187}$ All in all, the CJEU's approach is difficult to neatly classify, as confirmed by Prechal, who states that "while there is a rule of thumb - strict scrutiny wherever one of the prohibited grounds is at stake - the [Court] is rather pragmatic in its approach and not very principled, sometimes contrary to its own declaration of equality, and non-discrimination being fundamental principles or rights". ${ }^{188}$

\section{Volumes of references for preliminary ruling}

Although non-discrimination is one of the major issues on which the CJEU has rendered decisions in the past years, mostly in a favourable manner to applicants who claimed to have been discriminated against, having a look at the references for preliminary ruling brought to the Court since the 2000s regarding non-discrimination gives a good impression of the existence of hierarchies of referrals between the grounds protected. The amount of references largely varies for each of the different protected grounds. While high levels of references generally indicate a high level of litigation at the level of EU member states (all things considered) and thus is a good indicator of the importance of the issue, a lower level indicates a lower willingness or need (e.g. is the application of the law clear enough?) either on the side of national courts to bring the issue in front of the CJEU, or on the side of public interest lawyers or private parties to litigate cases on the issues concerned.

It is striking that the first references for religious discrimination have only been made in 2015 and amount to two cases only, while Directive 2000/78/EC protecting among others from religious discrimination has been passed in 2000 and transposed at the latest in $2003 .{ }^{189}$ In the same vein, the first references for racial discrimination deemed admissible by the Court have been made only in 2007 and then in 2011, ${ }^{190}$ while the transposition delay of Directive 2000/43/EC was 2003. In contrast, age discrimination has been the object of references for preliminary rulings from national courts much earlier, since 2004 already. At the same time, the number of references for age discrimination has surpassed all other grounds, amounting to 55 references brought to the Court by national courts over the period 20042015 according to the last CURIA update. ${ }^{191}$ It is interesting to notice that a majority of decisions regarding age discrimination originate from references for preliminary ruling by German courts $(50,9 \%)$, and to a lesser extent, Austrian and Danish courts (respectively 14,5\% and 10,9\%). This is due mainly to the ageing structure of their labour market. Preliminary referrals on other grounds have been far less numerous, although some disability case law is developing progressively. This compares to 12 references only for disability ${ }^{192}$ and 9 for sexual orientation ${ }^{193}$ which rank respectively second and third in the hierarchy of references. After age, disability and sexual orientation arrives race, with only 9 references, 4 of which have been deemed inadmissible. Besides, when referred, the question asked to

\footnotetext{
187 The intersection of gender, race, culture and religion and the question of female autonomy and patriarchy are completely silenced. See (nr. 72 and 74).

${ }^{188}$ Prechal, 'Discrimination does not fall down from heaven': the context and evolution of non-discrimination in EU law, 11

${ }^{189}$ It is not surprising that these references arise from France and Belgium. Preliminary references based on religion: Achbita (nr. 72) and Bougnaoui (nr. 74);

${ }^{190}$ Preliminary references based on race: Feryn (nr. 49) in 2007 and then Nikolava (nr. 52) in 2014 recognised discrimination but before this Vajnai in 2004, Agafitei in 2010 and Belov in 2011 were deemed inadmissible and no discrimination was found in Wardyn in 2009. C-668/15 Jyske Finans A/S v Ligebehandlingsncevnet, acting on behalf of Ismar Huskic is pending since 2015 .

${ }^{191}$ See the annex of this paper. There have been 51 references for preliminary ruling concerning the sole ground of age and 4 references concerning multiple grounds, including age. This amounts to 55 references.

${ }^{192}$ So far I have identified 10 references including joined and pending cases on the sole basis of disability, and 2 references on the basis of multiple grounds, among which disability. See annex.

${ }^{193}$ So far I have identified 8 references including joined cases on the sole basis of sexual orientation, and 1 reference on the basis of multiple grounds, among which sexual orientation. See annex.
} 
the CJEU as regards disability, sexual orientation and race were more basic than for age because subject to less exceptions. ${ }^{194}$ At the bottom of the hierarchy comes religion, with only two references and where the CJEU has found no directly discriminatory character in a rule prohibiting Islamic headscarf at work, and has accepted its potentially legitimate nature in case of indirect discrimination. ${ }^{195}$ It seems that the new developments brought by Directive 2004/113/EC to the historical protection of gender equality have also provoked little effusion at the national level, with only two decisions since its transposition deadline in 2007. ${ }^{196}$

All in all, there is therefore a de facto hierarchy, linked to its de jure equivalent, arising from the implementation by the CJEU of existing justifications and the level of scrutiny associated to each protected ground, and partially linked to its underlying rationale. This de facto hierarchy also stems from the references made by national courts that vary for each protected ground. Combined, the de jure and de facto hierarchies create an uneven equality protection which is problematic for the EU. At the same time, this hierarchy of multiple nature reflects what De Witte calls an "hybrid model", that is the "construction of a distinct multilevel governance regime in the field of antidiscrimination [that] combines the strengths of the rights approach with those of an experimental governance agenda." 197

\section{Conclusion: A tale of two diverging rationales, reconciled in a hybrid but effective principle}

Despite a new rationale promoting a genuine protection of equality as a fundamental right, few references to the Charter as a primary source of law have been made. It seems that the CJEU is privileging a pragmatic approach in order to avoid a controversy similar to what happened in Germany after Mangold. While non-discrimination law has lately been vested with the dimension of a fundamental right, and its underlying narrative has changed, this has affected the actual content of nondiscrimination rights in a minor way. In fact, in the hands of the EU, non-discrimination law remains obviously anchored in the market, guaranteeing market access rights as the core of its equality protection. This ensures that non-discrimination law remains within the scope of EU law, and at the same time covers important parts of the typical subset of social relationships - work and consumption -, especially in the case of race and gender, protected both within the labour market and in the access to goods and services. However, non-discrimination law punctually goes beyond the market, as in the case of the protection from racial discrimination. This is very far-reaching and probably extends to the very limits of what EU law can do in terms of equality protection. The fact that the adoption of the Race Equality Directive was unusually consensual indeed accounts for its exceptional character and the absence of challenge based on arguments related to a lack of EU competence. This taken into consideration, as well as the exceptional architecture dedicated to the protection of gender equality, allied to the current backlash and ongoing scepticism against the EU, casts serious doubts on the possibility of further legislative reforms in the near future. By way of illustration, despite the eight-year-long negotiations of the proposal for a so-called horizontal directive (2008 until today), and despite continuously renewed efforts to reach an agreement, the reform has consistently been blocked in the absence of unanimity. Besides, uncertainties remain as regards the place of the Charter and its wide range of protected

\footnotetext{
${ }^{194}$ They concerned for instance the definitions of the grounds, the exclusion from benefits of same-sex partners, etc. In the case of race, it could also be explained by the political unwillingness to challenge EU competences as granted by Directive 2000/43/EC or that the protection reflects protection already granted by national law.

${ }^{195}$ See (nr. 72) and (nr. 74).

196 These are the landmark case C-236/09 Test-Achats, which has however given rise to a small revolution (see nr. 38); and C318/13 $X$ according to the CURIA search database. No comprehensive search was run on the basis of the existing 6 directives and relevant Treaty provisions for gender non-discrimination, but the amount of preliminary references is very high, as the legislation has been available for a much longer period of time.

197 De Witte, 'New Institutions for Promoting Equality in Europe: Legal Transfers, National Bricolage and European Governance', 73
} 
categories under the developing general principle of non-discrimination. The reach and boundaries of non-discrimination law are therefore blurry, and the non-discrimination battle seems to have lost priority. This is problematic in light of the uneven nature of the present protection, which privileges certain identity traits over others. At the current stage, the EU is a more legally protected place for women and people of colour than for gays or persons with disabilities. The tacit nature of hierarchies in equality protection - result of political backlash, and not of an explicit political and societal debate - gives wrong signals in terms of prioritisation of values. One necessary next step for the EU to take, within its competence, is therefore to extend market access rights to level off the protection of all grounds. However, the pushback has led to different make up solutions, such as a more bottom-up and horizontal enforcement through the national equality bodies, or the interpretation of the binding Charter in the hands of the CJEU. In fact, as a fundamental right, equality - or its negative form non-discrimination is also a general principle towards which the Treaty, the Charter, the directives, the various international conventions and the member states' constitutional traditions converge. The general principle of nondiscrimination is therefore a powerful weapon in the hands of the Court's judges to fight against inequalities. Due to its controversial nature, it still tends to remain a solution of last resort, yet represents a safeguard for the Union's equal citizenship, and could prove an instrument at the Court's disposal to act against rising intolerance. The general principle of non-discrimination could also be used as a tool to level up the currently hierarchical protection of equality. In a period of multi-facetted crisis, the very blurriness of the potential boundaries of non-discrimination law could deal as an opportunity to give strong and reassuring signals regarding the centrality of equality and tolerance in a pluralistic society such as the EU. Hence, in the near future, non-discrimination law has the power to prove a double-edged sword, triggering controversy at the member states' level, but also fulfilling the crucial function of a supranational protection of some of the core values of EU citizenship. However, the latest signals given by the Court of Justice show more restraint than bravery, confirming the dissonance between a bold discourse depicting the EU as a human rights promoter and the very functional nature of the EU legal order. 


\section{Annex}

\section{Listing of references for preliminary ruling based on Directive 2000/78/EC and Directive 2000/43/EC}

This annex presents the results and search procedure linked to the listing and analysis of all references for preliminary ruling made based on Directive 2000/78/EC and Directive 2000/43/EC contained in Part III. 3) B. It contains all preliminary references for closed cases publicly available from the CURIA website. No search combination has yielded satisfactory results in terms of the preliminary references based on directives 2000/43/EC and 2000/78/EC in pending cases. The charts thus show the relevant pending cases found so far, but its systematisation is work in progress, as it requires searching for references to the two directives through the approximately 900 cases that are currently pending in front of the Court. Nevertheless, the following tables give a good overview of the architecture of references for preliminary ruling.

- RPR: reference for preliminary ruling

- In bold: references for pending and joined cases that did not appear in the various searches on the CURIA website

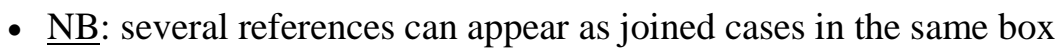

\begin{tabular}{|c|c|c|c|c|c|c|}
\hline \multicolumn{7}{|c|}{ Directive 2000/78/EC } \\
\hline$\#$ & Age & Disability & $\begin{array}{c}\text { Religion } \\
\text { Belief }\end{array}$ & $\begin{array}{c}\text { Sexual } \\
\text { orientation }\end{array}$ & Multiple & $\begin{array}{l}\text { Unknown } \\
\text { ground }\end{array}$ \\
\hline$\# 1$ & $\begin{array}{l}2004 \\
\text { C-144/04 Mangold } \\
\text { (RPR from Germany) }\end{array}$ & $\begin{array}{l}2005 \\
\text { C-13/05 } \\
\text { Chacón } \\
\text { Navas (RPR } \\
\text { from Spain) }\end{array}$ & $\begin{array}{l}2015 \\
\text { C-157/17 } \\
\text { Achbita } \\
\text { (RPR from } \\
\text { Belgium) - } \\
\text { pending }\end{array}$ & $\begin{array}{l}2006 \\
\text { C-267/06 Maruko } \\
\text { (RPR from Germany) }\end{array}$ & $\begin{array}{l}2010 \\
\text { C-415/10 } \\
\text { Meister (RPR } \\
\text { from } \\
\text { Germany) } \\
\text { - Sex } \\
\text { - Age } \\
\text { - Ethnic } \\
\text { origin }\end{array}$ & $\begin{array}{l}2010 \\
\text { C-310/10 } \\
\text { Agafiţei } \\
\text { and Others } \\
\text { (RPR from } \\
\text { Romania) } \\
\text { - + Race }\end{array}$ \\
\hline \#2 & $\begin{array}{l}2004 \\
\text { C-261/04 Schmidt } \\
\text { (RPR from Germany) }\end{array}$ & $\begin{array}{l}2006 \\
\text { C-303/06 } \\
\text { Coleman } \\
\text { (RPR from } \\
\text { UK) }\end{array}$ & $\begin{array}{l}2015 \\
\text { C-188/15 } \\
\text { Bougnaoui } \\
\text { et ADDH } \\
\text { (RPR from } \\
\text { France) - } \\
\text { pending }\end{array}$ & $\begin{array}{l}2008 \\
\text { C-147/08 Römer } \\
\text { (RPR from Germany) }\end{array}$ & $\begin{array}{l}2011 \\
\text { C-152/11 } \\
\text { Odar (RPR } \\
\text { from } \\
\text { Germany) } \\
\text { - Age } \\
\text { - Disability }\end{array}$ & $\begin{array}{l}2013 \\
\text { C-89/13 } \\
\text { D'Aniello } \\
\text { and Others } \\
\text { (RPR from } \\
\text { Italy) }\end{array}$ \\
\hline \#3 & $\begin{array}{l}2005 \\
\text { C-411/05 Palacios de } \\
\text { la Villa (RPR from } \\
\text { Spain) }\end{array}$ & $\begin{array}{l}2011 \\
\text { Joined cases } \\
\text { C-335/11 and } \\
\text { C-337/11 HK } \\
\text { Danmark } \\
\text { (RPR from } \\
\text { Denmark) }\end{array}$ & & $\begin{array}{l}2011 \\
\text { Joined cases } \\
\text { C-124/11, C-125/11 } \\
\text { and C-143/11 } \\
\text { Karen Dittrich and } \\
\text { Robert Klinke and } \\
\text { Jörg-Detlef Müller v } \\
\text { Bundesrepublik } \\
\text { Deutschland (RPR } \\
\text { from Germany) }\end{array}$ & $\begin{array}{l}2012 \\
\text { C-363/12 Z. } \\
\text { (RPR from } \\
\text { Ireland) } \\
\text { - Sex } \\
\text { - Disability }\end{array}$ & $\begin{array}{l}2012 \\
\text { C-361/12 } \\
\text { Carratù } \\
\text { (RPR from } \\
\text { Italy) }\end{array}$ \\
\hline \#4 & $\begin{array}{l}2006 \\
\text { C-87/06 Pascual } \\
\text { Garcia (RPR from } \\
\text { Spain - withdrawn }\end{array}$ & $\begin{array}{l}2012 \\
\text { C-356/12 } \\
\text { Glatzel (RPR }\end{array}$ & & $\begin{array}{l}2012 \\
\text { C-81/12 } \\
\text { Asociația Accept } \\
\text { (RPR from Romania) }\end{array}$ & $\begin{array}{l}2015 \\
\text { C-423/15 } \\
\text { Kratzer (RPR }\end{array}$ & $\begin{array}{l}2013 \\
\mathrm{C}-22 / 13\end{array}$ \\
\hline
\end{tabular}




\begin{tabular}{|c|c|c|c|c|c|}
\hline & $\begin{array}{l}\text { after decision in } \\
\text { Palacios) }\end{array}$ & $\begin{array}{l}\text { from } \\
\text { Germany) }\end{array}$ & & $\begin{array}{l}\text { from } \\
\text { Germany) } \\
\text { - Sex } \\
\text { - Age }\end{array}$ & $\begin{array}{l}\text { Mascolo } \\
\text { (RPR from } \\
\text { Italy) }\end{array}$ \\
\hline \#5 & $\begin{array}{l}2006 \\
\text { C-427/06 Bartsch } \\
\text { (RPR from Germany) }\end{array}$ & $\begin{array}{l}2013 \\
\text { C-354/13 } \\
\text { FOA (Kaltoft) } \\
\text { (RPR from } \\
\text { Denmark) }\end{array}$ & $\begin{array}{l}2012 \\
\text { C-267/12 Hay (RPR } \\
\text { from France) }\end{array}$ & $\begin{array}{l}2015 \\
\text { C-443/15 } \\
\text { Parris (RPR } \\
\text { from Ireland) } \\
\text { - Age } \\
\text { - Sexual } \\
\text { orientation }\end{array}$ & $\begin{array}{l}2013 \\
\text { C-61/13 } \\
\text { Forni (RPR } \\
\text { from Italy) }\end{array}$ \\
\hline \#6 & $\begin{array}{l}2007 \\
\text { C-388/07 Age } \\
\text { Concern England } \\
\text { (RPR from UK) }\end{array}$ & $\begin{array}{l}2015 \\
\text { C-198/15 } \\
\text { Invamed } \\
\text { Group } \\
\text { and Others } \\
\text { (RPR from } \\
\text { UK) }\end{array}$ & $\begin{array}{l}2012 \\
\text { C-610/12 Peter (RPR } \\
\text { from Germany) }\end{array}$ & & $\begin{array}{l}2013 \\
\text { C-62/13 } \\
\text { Racca (RPR } \\
\text { from Italy) }\end{array}$ \\
\hline \#7 & $\begin{array}{l}2007 \\
\text { C-555/07 } \\
\text { Kücükdeveci (RPR } \\
\text { from Germany) }\end{array}$ & $\begin{array}{l}2015 \\
\text { C-395/15 } \\
\text { Daouidi } \\
\text { (RPR from } \\
\text { Spain) }\end{array}$ & & & $\begin{array}{l}2013 \\
\text { C-63/13 } \\
\text { Russo (RPR } \\
\text { from Italy) }\end{array}$ \\
\hline \#8 & $\begin{array}{l}2008 \\
\text { C- } 88 / 08 \text { Hütter (RPR } \\
\text { from Austria) }\end{array}$ & $\begin{array}{l}2015 \\
\text { C-406/15 } \\
\text { Milkova (RPR } \\
\text { from } \\
\text { Bulgaria) }\end{array}$ & & & $\begin{array}{l}2016 \\
\text { C-27/16 } \\
\text { Marinkov } \\
\text { (RPR from } \\
\text { Bulgaria) } \\
\bullet+\text { Sex }\end{array}$ \\
\hline \#9 & $\begin{array}{l}2008 \\
\text { C-229/08 Wolf (RPR } \\
\text { from Germany) }\end{array}$ & $\begin{array}{l}2016 \\
\text { C-270/16 } \\
\text { Carlos } \\
\text { Enrique Ruiz } \\
\text { Conejero } \\
v \quad \text { Ferroser } \\
\text { Servicios } \\
\text { Auxiliares } \\
\text { S.A. and } \\
\text { Ministerio } \\
\text { Fiscal (RPR } \\
\text { from Spain) - } \\
\text { pending }\end{array}$ & & & \\
\hline$\# 10$ & $\begin{array}{l}2008 \\
\text { C-341/08 Petersen } \\
\text { (RPR from Germany) }\end{array}$ & & & & \\
\hline \#11 & $\begin{array}{l}2008 \\
\text { C-499/08 } \\
\text { Ingeniørforeningen } i \\
\text { Danmark (RPR from } \\
\text { Denmark) }\end{array}$ & & & & \\
\hline \#12 & $\begin{array}{l}2009 \\
\text { C-45/09 Rosenbladt } \\
\text { (RPR from Germany) }\end{array}$ & & & & \\
\hline \#13 & 2009 & & & & \\
\hline
\end{tabular}




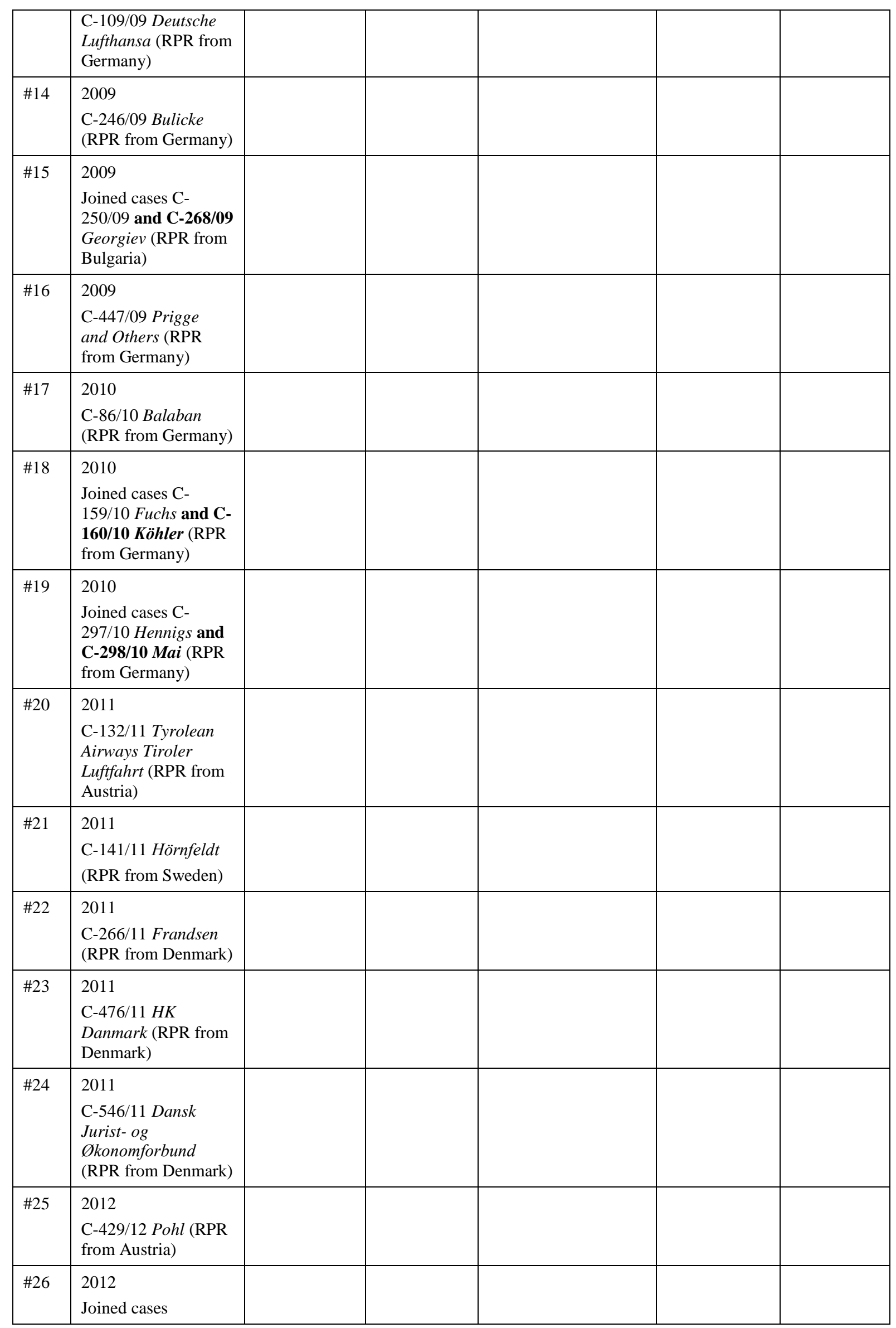




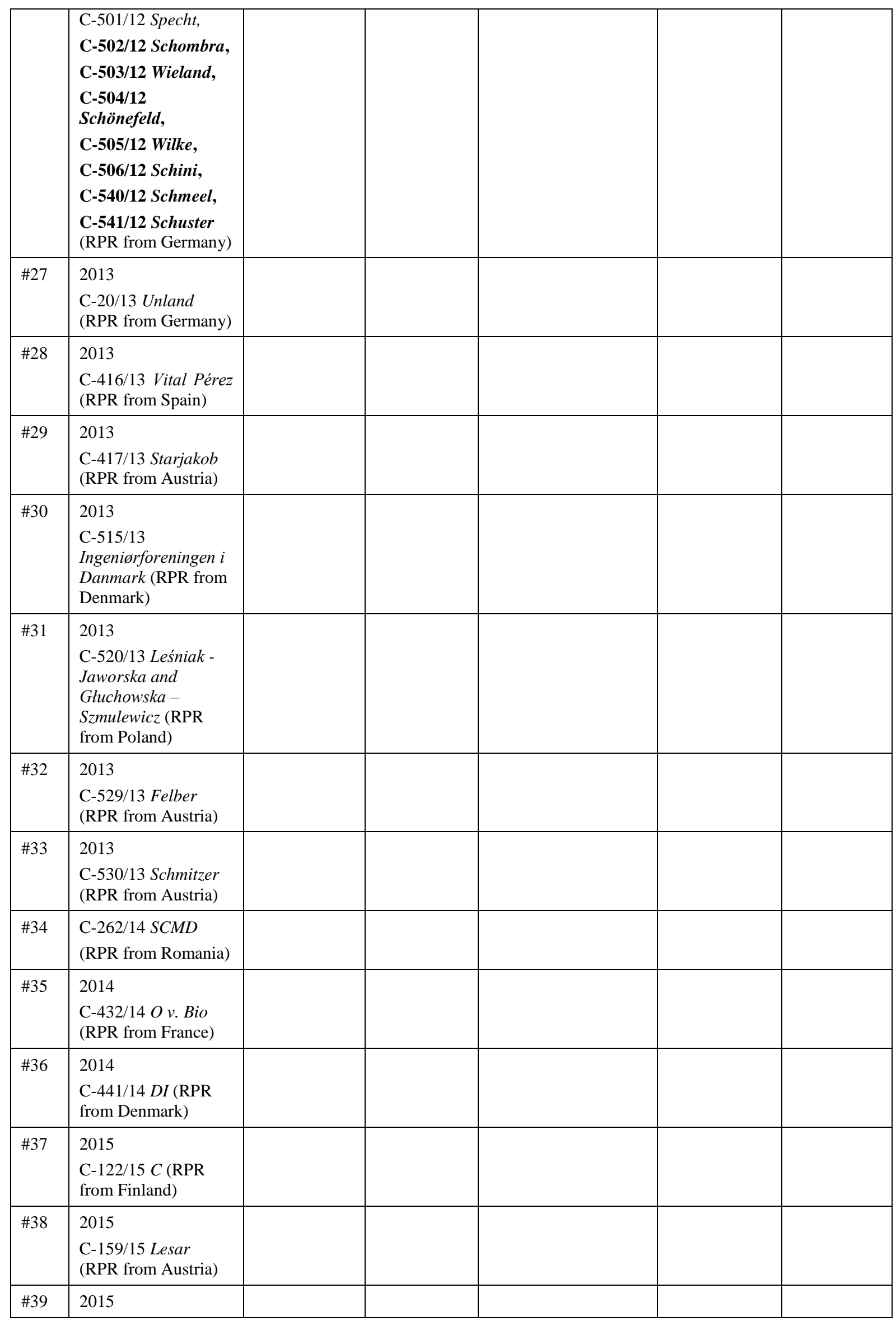




\begin{tabular}{|l|l|l|l|l|l|l|}
\hline & $\begin{array}{l}\text { C-258/15 Salaberria } \\
\text { Sorondo (RPR from } \\
\text { Spain) }\end{array}$ & & & & & \\
\hline$\# 40$ & $\begin{array}{l}2015 \\
\text { C-539/15 Bowman } \\
\text { (RPR from Austria) }\end{array}$ & & & & & \\
\hline \#41 & $\begin{array}{l}\text { C-548/15 De Lange } \\
\text { RPR from the } \\
\text { Netherlands) }\end{array}$ & & & & & \\
\hline Total & $\begin{array}{l}51 \text { RPR } \\
\text { Total }\end{array}$ & 10 RPR & 2 RPR & 8 RPR & & \\
\hline
\end{tabular}

\begin{tabular}{|c|c|}
\hline \# & $\begin{array}{l}\text { Directive 2000/43/EC } \\
\text { Race and ethnic origin }\end{array}$ \\
\hline$\# 1$ & $\begin{array}{l}2004 \\
\text { Case-328/04 Vajnai (RPR from Hungary) }\end{array}$ \\
\hline$\# 2$ & $\begin{array}{l}2007 \\
\text { C-54/07 Feryn (RPR from Belgium) }\end{array}$ \\
\hline$\# 3$ & $\begin{array}{l}2009 \\
\text { C-391/09 Runevič-Vardyn and Wardyn (RPR from Lithuania) }\end{array}$ \\
\hline$\# 4$ & $\begin{array}{l}2010 \\
\text { C-310/10 Agafiţei and Others (RPR from Romania) } \\
\text { - Directive 2000/78/EC }\end{array}$ \\
\hline$\# 5$ & $\begin{array}{l}2010 \\
\text { C-415/10 Meister (RPR from Germany) } \\
\text { - Age } \\
\text { - Sex }\end{array}$ \\
\hline \#6 & $\begin{array}{l}2010 \\
\text { C-571/10 Kamberaj (RPR from Italy) }\end{array}$ \\
\hline$\# 7$ & $\begin{array}{l}2011 \\
\text { C-394/11 Belov (RPR from Bulgaria) }\end{array}$ \\
\hline \#8 & $\begin{array}{l}2014 \\
\text { C-83/14 CHEZ Razpredelenie Bulgaria (RPR from Bulgaria) }\end{array}$ \\
\hline$\# 9$ & $\begin{array}{l}2015 \\
\text { C-668/15 Jyske Finans A/S (RPR from Denmark) - pending } \\
\text { - Race } \\
\text { - Nationality }\end{array}$ \\
\hline
\end{tabular}

\section{Search procedure:}

This data was obtained by doing a search on the CURIA database with the following criteria:

- Period or date = "All types of dates"; period= "from 01/01/2000 to 10/01/2017" 
- Court = "Court of Justice"

- References to case-law or legislation $=[$ Search in = "Grounds of judgment, Operative part"; Category = "Directive"; Number = "78"; Year = "2000"; ]

- Documents $=$ Documents published in the ECR : Orders - Information (on unpublished decisions)

Documents not published in the ECR : Orders (All)

Notices published in OJ : Cases brought

Period from $01 / 01 / 2000$ to $11 / 01 / 2017$

It gave 103 results, ${ }^{198}$ which I all filtered (selecting only the applications) and classified per ground invoked in order to find out the amount of national references for preliminary ruling made for each directive and for each ground. I eliminated all cases which were not national references for preliminary ruling, checked if references that had been treated as joined cases did not appear in the search and add them where applicable, and filtered out all applications that appeared but did not mention directive 2000/78/EC in their questions to the Court. ${ }^{199}$ The search does not show the preliminary references that have not yet been decided on by the Court. As a consequence, the two existing religious discrimination cases did not appear in the search, as well as preliminary references concerning discrimination on grounds of ethnicity and disability (in bold in the Annex).

I combined this search with larger searches run based on less restricting criteria in order to avoid missing anything, as the search tool of the CURIA website poses some issues in terms of exhaustiveness.

One example is the following search, which gave 227 results, which I filtered according to the same procedure as for the first search. The criteria are as follows ${ }^{200}$ :

- Period or date $=$ "Date of the lodging of the application initiating proceedings"; period= "from 01/01/2000 to 23/01/2017"

- References to case-law or legislation $=[$ Search in $=$ "Grounds of judgment, Operative part, Opinion"; Category = "Directive"; Number = "78"; Year = "2000"; ]

- Documents $=$ Documents published in the ECR : Orders - Information (on unpublished decisions)

Documents not published in the ECR : Orders ( All )

Notices published in OJ : Cases brought - Cases closed

Period from 01/01/2000 to 23/01/2017

Search procedure for the pending cases on non-discrimination matters: http://curia.europa.eu /juris/liste.jsf?pro $=\& \operatorname{lgrec}=$ en $\&$ nat $=$ or $\&$ oqp $=\&$ dates $=\& \lg =\&$ language $=$ en $\&$ jur $=\mathrm{C} \% 2 \mathrm{CT} \% 2 \mathrm{CF} \& \mathrm{cit}=$ no ne $\% 252 \mathrm{CC} \% 252 \mathrm{CCJ} \% 252 \mathrm{CR} \% 252 \mathrm{C} 2008 \mathrm{E} \% 252 \mathrm{C} \% 252 \mathrm{C} \% 252 \mathrm{C} \% 252 \mathrm{C} \% 252 \mathrm{C} \% 252 \mathrm{C} \% 252 \mathrm{C} \% 25$ $2 \mathrm{C} \% 252 \mathrm{C} \% 252 \mathrm{Ctrue} \% 252 \mathrm{Cfalse} \% 252 \mathrm{Cfalse} \& \mathrm{td}=\% 3 \mathrm{BALL} \& \mathrm{pcs}=$ Oor $\& a v g=\&$ page $=1 \&$ mat=DISC $\% 252$ Cor\&etat $=$ pend $\&$ jge $=\&$ for $=\&$ cid $=478994$

I repeated the search for Directive 2000/43/EC on race discrimination with the same criteria, just changing the directive number (and the corresponding CELEX number).

\footnotetext{
198 The link for this search is:

http://curia.europa.eu/juris/documents.jsf?page=1\&pro=\&lgrec=en\&nat=or\&oqp=\&dates=\%2524type $\% 253$ Dpro $\% 2524$ mode $\% 253$ DfromTo\%2524from $\% 253 \mathrm{D} 2000.01 .01 \% 2524$ to $\% 253 \mathrm{D} 2017.01 .10 \& 1 \mathrm{~g}=\&$ language $=\mathrm{en} \& \mathrm{jur}=\mathrm{C} \& \mathrm{cit}=\mathrm{L} \% 252$ $\mathrm{CC} \% 252 \mathrm{CCJ} \% 252 \mathrm{CR} \% 252 \mathrm{C} 2008 \mathrm{E} \% 252 \mathrm{C} \% 252 \mathrm{C} 2000 \% 252 \mathrm{C} 78 \% 252 \mathrm{C} \% 252 \mathrm{C} \% 252 \mathrm{C} \% 252 \mathrm{C} \% 252 \mathrm{C} \% 252 \mathrm{C} \% 252 \mathrm{Ctru}$ e $\% 252$ Ctrue $\% 252$ Cfalse \&td $=\% 24$ mode $\% 3$ frromTo $\% 24$ from $\% 3 \mathrm{D} 2000.01 .01 \% 24$ to $\% 3 \mathrm{D} 2017.01 .11 \% 3 \mathrm{~B} \% 3 \mathrm{~B} \% 3 \mathrm{BPUB}$ $2 \% 2$ CPUB6\%3BNPUB2\%3BCOM1\%3BORDALL\&pcs=Oor\&avg=\&mat=or \&jge $=\&$ for $=\& c i d=510252$

199 These cases are C-268/06 Impact, C-17/05 Cadman, C-227/04 Lindorfer, C-55/07 Michaeler and Subito, C-73/07 Satakunnan Markkinapörssi and Satamedia, C-73/08 Bressol, C-101/08 Audiolux, C-123/10 Brachner, C-282/10 Dominguez, C-617/11 P Marcuccio v. Commission, C-5/12 Betriu Montull, C-38/13 Nierodzik, and C-311-13 Tümer.

200 The date is later in time, but this did not change anything in terms of recent results.
} 


\section{References}

\section{Case law}

C-43/75, Gabrielle Defrenne v Société anonyme belge de navigation aérienne Sabena $\left(n^{\circ} 2\right)$ EU:C:1976:56, [1976] ECR 455

C-152/84, M. H. Marshall v Southampton and South-West Hampshire Area Health Authority (Teaching) EU:C:1986:84, [1986] ECR 723.

C-144/04 Werner Mangold v Rüdiger Helm EU:C:2005:709, [2005] ECR I-09981

C-303/06 Coleman v Attridge Law and Steve Law EU:C:2008:415 [2008] ECR I-05603

C-54/07 Centrum voor gelijkheid van kansen en voor racismebestrijding $v$ Firma Feryn NV EU:C:2008:397, [2008] ECR I-05187

C-555/07 Seda Kücükdeveci v. Swedex GMBH \& Co. KG EU:C:2010:21, [2010] ECR I-00365

C-250/09 Vasil Ivanov Georgiev v Tehnicheski universitet - Sofia, filial Plovdiv. EU:C:2010:699, [2010] ECR I-11869

C-45/09 Gisela Rosenbladt v Oellerking Gebäudereinigungsges. mbH. EU:C:2010:601, [2010] ECR I09391

C-341/08 Domnica Petersen v Berufungsausschuss für Zahnärzte für den Bezirk Westfalen-Lippe EU:C:2010:4, [2010] ECR I-00047

C-232/09 Dita Danosa v LKB Līzings SIA EU:C:2010:674, [2010] ECR I-11405

C-236/09 Association Belge des Consommateurs Test-Achats ASBL and Others v Conseil des ministres [2011] EU:C:2011:100

C-147/08 Jürgen Römer v Freie und Hansestadt Hamburg EU:C:2011:286, [2011] ECR I-03591

C-447/09 Reinhard Prigge and Others v Deutsche Lufthansa AG. EU:C:2011:573 [2011] ECR I-08003

Joined cases C-297/10 and C-298/10 Sabine Hennigs $v$ Eisenbahn-Bundesamt and Land Berlin v Alexander Mai EU:C:2011:560, [2011] ECR I-07965

C-34/09 Gerardo Ruiz Zambrano v Office national de l'emploi (ONEm) EU:C:2011:124, [2011] ECR I-01177

C-256/11 Murat Dereci and Others v Bundesministerium für Inneres EU:C:2011:734, [2011] ECR 000.

C-415/10 Galina Meister v. Speech Design Carrier Systems GmbH EU:C:2012:217 [2012]

C-152/11, Johann Odar v. Baxter Deutschland GmbH EU:C:2012:772, [2012]

Joined cases C-335/11 and C-337/11 HK Danmark, acting on behalf of Jette Ring v Dansk almennyttigt Boligselskab and HK Danmark, acting on behalf of Lone Skouboe Werge v Dansk Arbejdsgiverforening acting on behalf of Pro Display A/S EU:C:2013:222, [2013]

C-476/11 H.K. Danmark acting on behalf of Glennie Kristensen v Experian A/S EU:C:2013:590, [2013]

C-394/11 Valeri Hariev Belov v CHEZ Elektro Balgaria AD and Others EU:C:2013:48, [2013]

C-83/14, CHEZ Razpredelenie Bulgaria AD v Komisa za zashtita ot diskiminatsia EU:C:2015:480, [2015]

C-149/10 Zoi Chatzi v Ypourgos Oikonomikon [2016] EU:C:2010:534 
C-157/15 Samira Achbita and Centrum voor gelijkheid van kansen en voor racismebestrijding $v$ G4S Secure Solutions NV EU:C:2016:382, [2016] Opinion of AG Kokott

C-188/15 Asma Bougnaoui and Association de défense des droits de l'homme (ADDH) v Micropole SA EU:C:2016:553, [2016] Opinion of AG Sharpston.

C-443/15 David L. Parris v Trinity College Dublin and Others EU:C:2016:897, [2016]

C-441/14 Dansk Industri (DI) v Succession Karsten Eigil Rasmussen EU:C:2016:278, [2016]

C-406/15 Petya Milkova v Izpalnitelen direktor na Agentsiata za privatizatsia i sledprivatizatsionen kontrol EU:C:2017:198, [2017]

C-157/15 Samira Achbita and Centrum voor gelijkheid van kansen en voor racismebestrijding $v$ G4S Secure Solutions NV EU:C:2017:203, [2017]

C-188/15 Asma Bougnaoui and Association de défense des droits de l'homme (ADDH) v Micropole SA EU:C:2017:204, [2017]

C-668/15 Jyske Finans A/S v Ligebehandlingsnovnet, acting on behalf of Ismar Huskic [pending]

Gareth Lee v Colin McArthur, Karen McArthur and Ashers Baking Company Limited [2016] NICA 39

\section{Legislation}

Council Directive 75/117/EEC of 10 February 1975 on the approximation of the laws of the Member States relating to the application of the principle of equal pay for men and women [1975] OJ L45/19

Council Directive 76/207/EEC of 9 February 1976 on the implementation of the principle of equal treatment for men and women as regards access to employment, vocational training and promotion, and working conditions [1976] OJ L39/40

Council Directive 79/7/EEC of 19 December 1978 on the progressive implementation of the principle of equal treatment for men and women in matters of social security [1978] OJ L6/24

Charter of Fundamental Rights of the European Union [2000] OJ C364/3

Council Directive 2000/43/EC of 29 June 2000 implementing the principle of equal treatment between persons irrespective of racial or ethnic origin [2000] OJ L180/22

Council Directive 2000/78/EC of 27 November 2000 establishing a general framework for equal treatment in employment and occupation [2000] OJ L303/16

Council Directive 2004/113/EC of 13 December 2004 implementing the principle of equal treatment between men and women in the access to and supply of goods and services [2004] OJ L373/37

Directive 2006/54/EC of the European Parliament and of the Council of 5 July 2006 on the implementation of the principle of equal opportunities and equal treatment of men and women in matters of employment and occupation (recast) [2006] OJ L204/23

Communication from the Commission to the European Parliament, the Council, the European Economic and Social Committee and the Committee of the Regions COM/2008/0426 final on a Proposal for a Council Directive on implementing the principle of equal treatment between persons irrespective of religion or belief, disability, age or sexual orientation SEC(2008) 2172 [2008] OJ C303/21 


\section{Policy, advocacy and institutional research documents}

Burri S and Schiek D, Multiple Discrimination in EU Law. Opportunities for legal responses to intersectional gender discrimination?, (European Commission, July 2009)

< http://ec.europa.eu/justice/gender-equality/files/multiplediscriminationfinal7september2009_en.pdf> accessed 19 May 2016

Burri S and McColgan A, Sex Discrimination in the Access to and Supply of Goods and Services and the Transposition of Directive 2004/113/EC (European Commission 2009)

< http://ec.europa.eu/justice/gender-equality/files/accesstogoodsandservicesfinal28may2009_en.pdf> accessed 5 May 2016

Burri S and Prechal S, EU Gender Equality Law: Update 2013 (European Commission 2014)

Chopin I and Niessen J, Proposals for Legislative Measures to Combat Racism and Promote Equal Rights in the European Union (Belmont Press 1998)

'Communication from the Commission to the European Parliament, the Council, the European Economic and Social Committee and the Committee of the Regions - Non-discrimination and equal opportunities: A renewed commitment' (Communication) COM (2008) 0420 final <http://data.consilium.europa.eu/doc/document/ST-11530-2008-INIT/fr/pdf>

Commission (EC), 'From Challenges to Opportunities: Towards a Common Strategic Framework for EU Research and Innovation funding' (Green Paper) COM (2011) 48

Commission (EC), Equality and non-discrimination in an enlarged European Union (Green Paper) COM (2004) 379 final

De Vos M, Beyond Formal Equality. Positive Action under Directives 2000/43/EC and 2000/78/EC (European Commission 2007)

Commission (EC), 'Tackling Multiple Discrimination. Practices, policies and laws' (2007)

Masselot A, Caracciolo Di Torella E and Burri S, Fighting Discrimination on the Grounds of Pregnancy, Maternity and Parenthood. The application of EU and national law in practice in 33 European countries (European Commission 2012) < http://ec.europa.eu/justice/gender-equality/files/your_rights/dis crimination_pregnancy_maternity_parenthood_final_en.pdf> accessed 5 May 2016

Saiz Arnaiz A and Torres Pérez A, Main trends in the recent case law of the EU Court of Justice and the European Court of Human Rights in the field of fundamental rights (European Commission 2012)

\section{Secondary sources}

Barbera M, 'The Role of the Equality Principle in the European Multilevel System' in Paciotti E (ed) I diritti fondamentali in Europa (Roma, Viella 2011)

Barnard C, EC Employment Law (Oxford EC Law Library, OUP 2006)

Forschungsinstitut für Deutsches und Europäisches Immobilienwirtschafts- und Genossenschaftsrecht an der HTW Berlin, 'Arbeitsrecht', Newsletter nr. 12 (Hochschule für Technik und Wirtschaft Berlin 2016) 
Burns R, 'A Hierarchy of Equalities: Gráinne de Búrca examines how the European Court of Justice is dealing with anti-discrimination laws' Ideas from NYU Law <http://www.law.nyu.edu /news/ideas/grainne-de-burca-eu-anti-discrimination> accessed 20/09/2016

Cornides J, 'Three Case Studies on 'Anti-Discrimination" (2012) 23 The European Journal of International Law

Craig P and De Búrca G, 'Equal Treatment and Non-Discrimination' in Craig P and De Búrca G (eds), EU Law: Text, Cases and Materials (OUP 2015)

De Búrca G, 'The Road Not Taken: The EU as a Global Human Rights Actor' (2011) 105 The American Journal of International Law 649

De Búrca G, 'The Trajectories of European and American Antidiscrimination Law' (2012) 60 American Journal of Comparative Law

De Búrca G, A hierarchy of equalities (Video, NYU Law 2016)

De Búrca G, Kilpatrick C and Scott J, Critical legal perspectives on global governance: Liber amicorum David M. Trubek (Hart Publishing 2013)

De Mol M, 'The Novel Approach of the CJEU on the Horizontal Direct Effect of the EU Principle of Non-Discrimination: (Unbridled) Expansionism of EU Law?' (2011) 18 Maastricht Journal of European and Comparative Law 109

De Witte B, 'The crumbling public/private divide: horizontality in European anti-discrimination law' (2009) 13 Citizenship Studies 515

De Witte B, 'New Institutions for Promoting Equality in Europe: Legal Transfers, National Bricolage and European Governance' (2012) 60 American Journal of Comparative Law

Delcher E, 'An overview of the case law on the prohibition of discrimination of the ECJ and the ECtHR' (Islandic Human Rights Centre, 2012) <http://www.humanrights.is/en/activities/equality-nondsicrimination/overview-of-the-case-law-on-the-prohibitation-of-discrimination-of-the-ecj-and-ecthr > accessed 10 May 2016

Ellis E and Watson P, EU Anti-Discrimination Law (OUP 2012)

Ellis E and Watson P, 'Exceptions to the non-discrimination principle' in Eeckhout $\mathrm{P}$ and Anderson D (eds), EU Anti-Discrimination Law (OUP 2012)

European Union Agency for Fundamental Rights and Council of Europe, Handbook on European NonDiscrimination Law (Publications Office of the European Union 2011)

Farkas L, 'Collective actions under European anti-discrimination law' (2014) 19 European Antidiscrimination Law Review 25

Fraser N, 'From Redistribution to Recognition? Dilemmas of Justice in a 'Post-Socialist' Age' (JulyAugust 1995) New Left Review

Fraser N, 'Rethinking recognition' (2000) 3 New Left Review

Fredman S, 'Double trouble: multiple discrimination and EU law' (2005) 2 European Antidiscrimination Law Review 13

Fredman S, 'Pasts and Futures: EU Equality law' in Bogg A and others (eds), Research Handbook of European labour Law (Edward Elgar Publishing 2016)

Fredman S, 'Substantive equality revisited' (2016) 14 International Journal of Constitutional Law 712 
Hinterhuber EM and Vasterling V, 'Gender and Diversity Studies in European Perspectives: International conference, 8-10 January 2015, Rhine-Waal University of Applied Sciences, Kleve' (2015) 5 Gender: Zeitschrift für Geschlecht, Kultur und Gesellschaft

Howard E, The EU Race Directive. Developing the Protection against Racial Discrimination within the $E U$ (Routledge 2010)

Kennedy D, 'Three Globalizations of Law and Legal Thought: 1850-2000' (2006) 19 The New Law and Economic Development

Kennedy D, 'The Globalisation of Critical Discourses on Law: Thoughts on David Trubek's Contribution' in De Búrca G and others (eds), Critical Legal Perspectives on Global Governance Liber Amicorum David M Trubek (Hart Publishing 2015)

Kilpatrick C, 'The Court of Justice and Labour Law in 2010: A New EU Discrimination Law Architecture' (2011) 40 Industrial Law Journal 280

Kochenov D, 'Citizenship without Respect: The EU's Troubled Equality Ideal' (2010) Jean Monnet Working Paper 08/10

Kochenov D, De Búrca G and Williams A (eds), Europe's Justice Deficit (Hart Publishing 2015)

Kukovec D, 'Law and the Periphery' (2015) 21 European Law Journal 406

McCrudden C, 'Thinking about the discrimination directives' (2005) 1 European Anti-discrimination Law Review 17

McDonald H, "Gay cake' row: born-again Christian bakers lose court appeal' The Guardian (24 October 2016) <https://www.theguardian.com/uk-news/2016/oct/24/born-again-christian-ashers-bakery-losecourt-appeal-in-gay-cake-row> accessed 25 October 2016

Micklitz H, 'Social justice and Access Justice in Private Law' (European University Institute 2011)

Micklitz H, 'A European Advantage in Legal Scholarship?' (European University Institute 2015)

Micklitz H-W, The Politics of Judicial Co-operation in the EU Sunday Trading, Equal Treatment and Good Faith (Cambridge University Press 2005), 165-291

Muir E, 'The Transformative Function of EU Equality Law' (2013) 5 European Review of Private Law 1231

Münch R, European governmentality: the liberal drift of multilevel governance (Routledge 2010)

Neuvonen PJ, 'Inequality in equality' in the European Union equality directives: A friend or a foe of more systematized relationships between the protected grounds?' (2015) 15 International Journal of Discrimination and the Law 222

Niessen J and Chopin I, 'The Starting Line and the Racial Equality Directive' in Niessen J and Chopin I (eds), The Development of Legal Instruments to Combat Racism in a Diverse Europe (Martinus Nijhoff Publishing 2004)

Prechal S, 'Achievements and Trends in EU Gender Equality Law' < http://www.euroinfo.ee/malta/pdf /c4.pdf> accessed 10 May 2016

Prechal S, 'Discrimination does not fall down from heaven': the context and evolution of nondiscrimination in EU law (2009) Eric Stein Working Paper no. 4 https://csesp.files.wordpress .com/2015/05/eswp-2009-04-prechal.pdf accessed 29 Septembre 2016 
Reich N, 'The Social, Political and Cultural Dimension of EU Private Law' in Schulze R and SchulteNölke H (eds), European Private Law - Current Status and Perspective (Sellier European Law Publishers 2011)

Reich N, 'The Impact of the Non-Discrimination Principle on Private Autonomy' in Leczykiewicz D and Weatherhill S (eds), The Involvement of EU Law in Private Law Relationships (Hart Publishing 2013)

Reich N, General Principles of EU Civil Law (Intersentia 2014), 59-88

Ruzza C, 'Human rights, anti-racism, and EU advocacy coalitions' in Morris L (ed) Rights: Sociological Perspectives (Routledge 2006)

Potter M, The EU 'Horizontal Directive’ (Northern Ireland Assembly 2011)

Shuibhne NN, '(Some of) The Kids Are All Right' (2012) 49 Common Market Law Review 349

Somek A, Engineering Equality. An Essay on European Anti-Discrimination Law (OUP 2011)

Somek A, 'The Preoccupation with Rights and the Embrace of Inclusion: A Critique' in Kochenov D and others (eds), Europe's Justice Deficit (Hart Publishing 2015)

Uyen Do T, '2011: A case odyssey into 10 years of anti-discrimination law' 12 European Antidiscrimination Law Review 11 <http://ec.europa.eu/justice/discrimination/files/antidiscriminati on_law_review_12_en.pdf $>$ accessed 17 May 2016

Verloo M, 'Multiple Inequalities, Intersectionality and the European Union' (2006) 13 European Journal of Women's Studies 211

Walby S, Armstrong J and Strid S, 'Intersectionality and the Quality of the Gender Equality Architecture' (2012) 19 Social Politics: International Studies in Gender, State \& Society 446

Zaccaroni G, "More on the horizontal direct effect of the principle of nondiscrimination on the ground of age: Dansk Industries (DI)' (EU Law Analysis, 14 July 2016)

$<$ http://eulawanalysis.blogspot.com/2016/07/more-on-horizontal-direct-effect-of.html> accessed 10

October 2016 
